\title{
LOKALNO PODNEBJE IN TOPOKLIMATSKA KARTA JEZERSKEGA
}

\author{
dr. Darko Ogrin*,Tanja Koželj**, dr. Miroslav Vysoudil ***
}

* Oddelek za geografijo, Filozofska fakulteta Univerze v Ljubljani, Aškerčeva 2, SI- 1000 Ljubljana

** Oddelek za geografijo, Filozofska fakulteta Univerze v Ljubljani, Aškerčeva 2, SI- I000 Ljubljana

*** Department of Geography, Faculty of Science, Palacký University Olomouc,

17. listopadu 12, CZ-77I46 Olomouc, Czech Republic

e-pošta: darko.ogrin@ff.uni-lj.si, tanja.kozelj@ff.uni-lj.si, miroslav.vysoudil@upol.cz

Izvirni znanstveni članek

COBISS 1.01

DOI: $10.4312 /$ dela.45.1.5-30

\section{Izvleček}

V prispevku so prikazane osnovne topoklimatske značilnosti Jezerskega, ki so rezultat splošnih podnebnih potez in specifičnih lokalnih razmer. Prostorsko najbolj razširjene topoklimatske enote so posledica razlik v osončenosti ter součinkovanja lokalnih reliefnih danosti in rabe tal. Prikazane so na pregledni topoklimatski karti v merilu $1: 25.000$.

Ključne besede: lokalno podnebje, topoklimatsko kartiranje, topoklimatska karta, termalni monitoring, Jezersko, Slovenija

\section{LOCAL CLIMATE AND TOPOCLIMATIC MAP OF JEZERSKO}

\begin{abstract}
The article deals with basic topoclimatic features of Jezersko resulting from the general climate characteristics and specific local conditions. The spatially most widely spread topoclimatic units result from insolation differences and interaction between local landform features and land use. They are presented on a generalized topoclimatic map in the scale of $1: 25,000$.
\end{abstract}

Key words: local climate, topoclimate mapping, topoclimatic map, thermal monitoring, Jezersko, Slovenia 


\section{UVOD}

Z izrazom topoklima označujemo specifične lokalne podnebne poteze, ki se oblikujejo pod vplivom značilnosti Zemljinega površja, predvsem reliefnih danosti (nadmorska višina, ekspozicija, naklon površja, reliefna izoblikovanost) in rabe površja (urbanizirane površine, gozdne površine, kmetijske površine, vodne površine ipd.). Osnovne poteze pa so odvisne od regionalnih in tudi globalnih podnebnih razmer. Pod vplivom površja se oblikujejo t. i. topoklimati, to so deli Zemljinega površja, ki imajo enake oziroma podobne podnebne razmere in imajo prostorski obseg od nekaj do $100 \mathrm{~km}^{2}$.

Raziskovanje vpliva lokalnih pokrajinskih razmer na podnebje ima v slovenski geografiji dolgo tradicijo. Študije so bile usmerjene na raziskovanje vpliva reliefa na lokalno podnebje (Ogrin D., 2000; Ogrin M., 2005), raziskovanje vpliva konkavnih oblik reliefa na minimalne temperature zraka (Gams, 1972; Žiberna, 1999; Ogrin M. in sod., 2006; Ogrin M., 2007; Ortar in sod., 2010) in oblikovanje termalnega pasu (Gams, 1996; Ogrin D., 2005, 2007; Žiberna, 1992). Raziskovali so odnos med reliefom in Sončevim obsevanjem (Gabrovec, 1996), pojav mestnega podnebja (Žiberna, 1991; Jernej, 2000; Konovšek, 2006) in pojav znižane meje sneženja (Strle, 2015). Manjšo tradicijo ima v slovenskem prostoru, npr. v primerjavi s Srednjo Evropo, kjer je ta del klimatogeografije zelo razvit (Mičietová, Pavličko, 2000; Sulzer, 2002; Polčák, 2000; Quit, 1965, 1990, 1994; Vysoudil, 1993, 1997, 2000; Vysoudil in sod., 2012 idr.), topoklimatsko kartiranje in izdelovanje topoklimatskih kart (Ogrin D., 2008; Selčan, Tomić, 2010; Ogrin D., Vysoudil, 2011; Vysoudil in sod., 2012; Ogrin D. in sod., 2013).

Z izjemo prispevkov Furlana in Koširja (1976) ter Popoviča (1992), ki obravnavata Jezersko predvsem kot klimatsko zdravilišče, obravnavana pokrajina še nima podrobnejšega prikaza lokalnih podnebnih razmer. Prispevek ima zato dva cilja. Prvi je na osnovi neposrednih in posrednih metod zaznavanja analizirati najpomembnejše topoklimatske značilnosti, s poudarkom na razlikah v osončenosti, na razporejanju temperature zraka ob radiacijskem vremenu in na lokalnih vetrovih. Drugi, ki izhaja iz prvega, pa je s pomočjo delnih topoklimatov izdelati sintezno topoklimatsko karto v merilu $1: 25.000$.

\section{METODE}

V metodološkem smislu lahko ugotavljamo topoklimatske značilnosti, pri katerih so pomembne predvsem razmere pri površju (aktivna plast), kjer poteka energijska izmenjava med površjem in ozračjem, s podrobnimi terenskimi meritvami in opazovanji (neposredne metode) ali pa s posrednimi metodami. Pri našem delu smo uporabili kombinacijo obojega. Sledili smo metodologiji, ki se je uveljavila pri topoklimatskih raziskavah v Srednji Evropi (Quitt, 1965, 1994; Vysoudil, 1993, 2000, 2009; Polčák, 2000, 2001), in jo ustrezno prilagodili lokalnim razmeram na Jezerskem, tudi na podlagi izkušenj izdelave topoklimatske karte Slovenske Istre (Ogrin D., Vysoudil, 2011) in doline Kamniške Bistrice (Ogrin D. in sod., 2013). Pri neposrednem spoznavanju lokalnih podnebnih razmer smo uporabili rezultate terenskih meritev in opazovanj, ki so bile v obdobju 2013-2015 opravljene posebej za potrebe te raziskave. Zaradi vloge razmer pri površju za oblikovanje topoklimatskih 
značilnosti večina meritev ni bila opravljena na standardni višini (te meritve so bolj reprezentativne za regionalne razmere), ampak nižje. Temperaturo zraka smo merili na 1,5 do $1,8 \mathrm{~m}$ nad površjem, veter na 1,8 do $2,5 \mathrm{~m}$ nad površjem, zastrtost obzorja zaradi reliefa in arhitektonskih ovir in s tem vpliv na insolacijo na 1,6 do 1,8 m nad tlemi.

S posrednimi metodami smo sklepali na lokalne podnebne poteze s pomočjo analize značilnosti površja, ki smo jo naredili s pomočjo GIS orodij. Pri reliefu smo upoštevali konkavnost, konveksnost, naklon in ekspozicijo. Pomagali smo si z digitalnim modelom višin s celično mrežo ločljivosti 12,5 m (Digitalni model višin ..., 2015). Trajanje insolacije in prejeto energijo Sončevega sevanja smo izračunali s pomočjo Solar Radiation orodij programskega paketa ESRI ArcGIS, ki upošteva astronomske dejavnike, oblikovanost reliefa in atmosferske dejavnike.

Vpliv vegetacijskih razmer in rabe tal na lokalno podnebje smo določali s pomočjo lidarskih podatkov (LIDAR, 2015), evidentirane dejanske rabe zemljǐš (Evidenca dejanske rabe, 2014) in katastra stavb (Kataster stavb, 2016). Rabo tal smo glede na njen vpliv na podnebne razmere kategorizirali $\mathrm{v}$ štiri razrede: površine $\mathrm{z}$ redkim oziroma brez rastlinstva, grmišča in travišča, gozd in pozidane površine. Evidentirana dejanska raba dobro zajema površine $\mathrm{z}$ redkim oziroma brez rastlinstva; za potrebe raziskave pa je neugodno, da kategorija gozd (raba_id $=2000$ ) vključuje tudi rušje, kategorija pozidanih površin $($ raba_id $=3000)$ pa tudi odprte pozidane površine, kot so parkirišča in ceste. Zato smo iz georeferenciranega in klasificiranega oblaka točk (GKOT) lidarskih podatkov s pomočjo programskih orodij Fugro Viewer in ArcGIS Spatial Analyst določili območja nizke (do 1 $\mathrm{m}$ ), srednje (1-4 m) in visoke vegetacije (nad $4 \mathrm{~m}$ ). Dobljeni sloj smo dopolnili z območji z redkim oziroma brez rastlinstva iz dejanske rabe tal (raba_id $=5000 / 6000 / 7000)$ in območji, kjer razdalja med stavbami iz katastra stavb ne presega $100 \mathrm{~m}$, ter dobljena območja uskladili z zgornjo gozdno mejo (Evidenca gozdnih sestojev, 2012).

$\mathrm{V}$ veliko pomoč pri sklepanju na vpliv vegetacije in rabe tal na temperaturne razmere površja in ozračja pri tleh so nam bili tudi termalni posnetki površja. Ti so bili za potrebe raziskave narejeni s prenosno infrardečo kamero Fluke Ti55 IR fusion technology. Termalni posnetki so nam služili pri identifikaciji območij, ki imajo podobne temperaturne značilnosti aktivnega dela površja (slika 1), kar nam je bilo v pomoč pri izločanju topoklimatskih enot pri topoklimatskem kartiranju (Vysoudil, Ogrin D., 2009).

Osnovo topoklimatske karte Jezerskega (slika 6) predstavlja rastrski sloj obsijanosti površja oziroma prejete energije Sončevega sevanja. Slika je generalizirana, saj smo izločili območja, manjša od 1 ha. Na osnovni rastrski sloj smo dodali izključujoče se vektorske sloje in jih prikazali s šrafurami: $\mathrm{z}$ rjavo šrafuro območja višjega gorskega sveta, $\mathrm{z}$ rumeno šrafuro konkavne predele, $\mathrm{z}$ zeleno območja vrhov in grebenov. Tudi območja rabe tal smo posplošili tako, da smo izločili območja, ki so manjša od 1 ha. Prikazali smo jih s črnimi šrafurami na celotnem območju, razen na območjih vrhov in grebenov. Predele pod vplivom zračnih tokov smo označili s puščicami različnih barv in debelin. Prevladujoče smeri vetrov nakazuje vetrovna roža. Za orientacijo smo dodali vektorske sloje vodotokov cest, državne meje in vrhov ter nekaterih topografskih imen. Zaradi lažje grafične obdelave in priprave za tisk smo sloje izvozili iz programa ArcMap in končno karto sestavili v programu Adobe Illustrator. 
Slika 1: Razlike v temperaturi nekaterih tipov aktivnega dela površja na Jezerskem: a. asfaltirane površine v primerjavi s poraščenim površjem; b. vodotok v primerjavi z neenakomerno poraščenim travnikom (termalni posnetki in njihova obdelava: M. Vysoudil).

Fig. 1: Differences in temperature between some types of surface at Jezersko: a. asphalt surfaces in comparison with overgrown surface; $b$. water stream in comparison with unequally overgrown meadow (thermal images and their processing: M. Vysoudil).

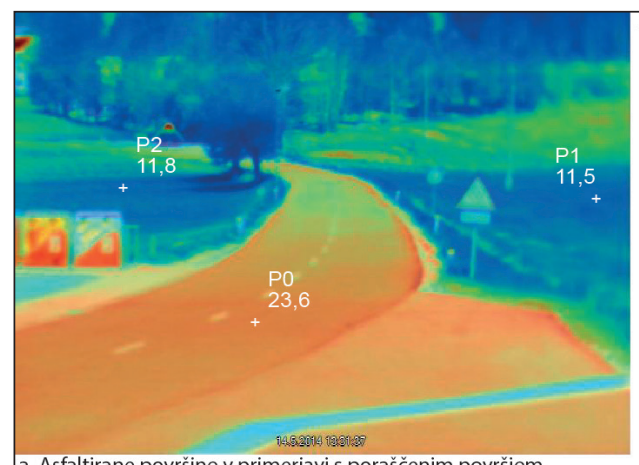

a. Asfaltirane površine v primerjavi s poraščenim površjem.

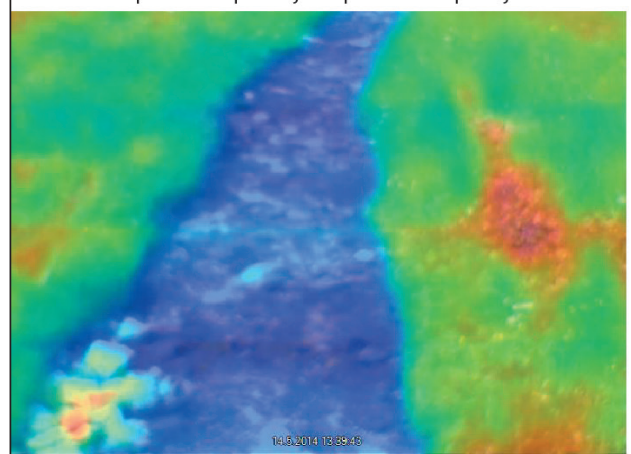

b. Vodotok v primerjavi z neenakomerno poraščenim travnikom.
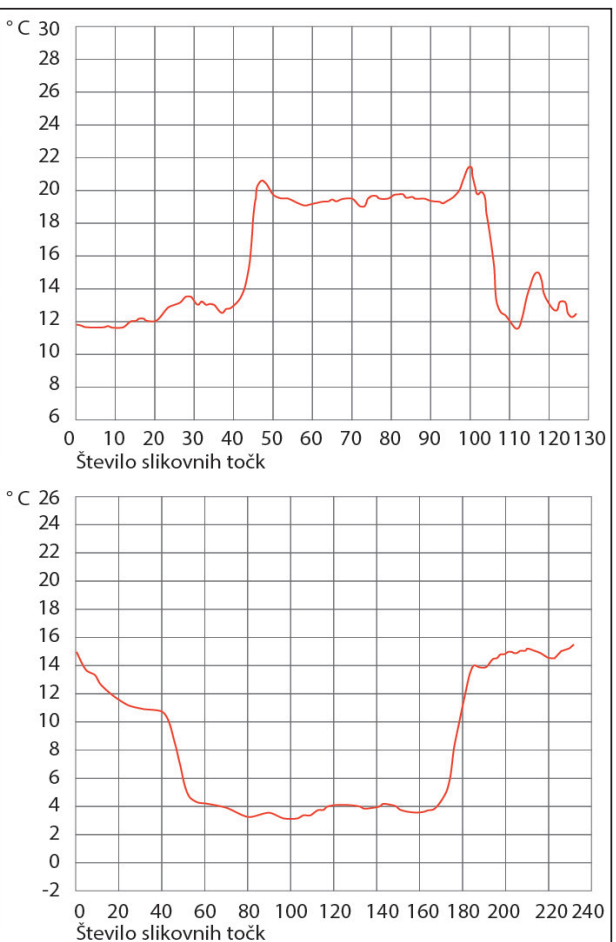

\section{RAZISKOVALNO OBMOČJE}

Raziskovalno območje ima površino $36,2 \mathrm{~km}^{2}$ in sovpada $\mathrm{z}$ osrednjim delom občine Jezersko, ki leži v severnem, alpskem delu Slovenije. Jedro pokrajine predstavlja Jezerska kotlinica z ledeniškima dolinama Ravenska in Makekova Kočna ter Spodnji kraj v povirnem delu Kokre. Spodnji kraj leži na nadmorski višini 700 do 800 m, Jezerska kotlinica z Ravensko in Makekovo Kočno pa večinoma med 900 in 1000 m. Kotlinsko-dolinski del raziskovalnega območja obdaja visokogorje Karavank in Kamniško-Savinjskih Alp z najvišjimi vrhovi med 1600 in nekaj nad 2500 m. Jezerska kotlinica, ki je nasuta z ledeniško-rečnimi sedimenti, predstavlja kamninski stik med triasnimi apnenci in dolomiti južno od nje (v delu, ki pripada Kamniško-Savinjskim Alpam) ter devonskimi apnenci in manj prepustnimi karbonskimi skrilavci in peščenjaki v severnem delu obravnavanega 
območja, ki pripada Karavankam (Buser, Cajhen, 1975). Karavanški del Jezerskega je nižji, bolj položen in z gostejšo rečno mrežo, južnejši pa višji, kraški in bolj razčlenjen. Po Jezerski kotlinici teče potok Jezernica, ki izvira v Ravenski Kočni, napaja Planšarsko jezero in se pri kraju Spodnje Jezersko zliva v Kokro.

Nižji deli Jezerskega imajo podnebje nižjega gorskega sveta (povprečna temperatura najhladnejšega meseca pod $-3{ }^{\circ} \mathrm{C}$ in najtoplejšega nad $\left.10{ }^{\circ} \mathrm{C}\right)$, gorati obod pa podnebje višjega gorskega sveta s povprečno temperaturo najtoplejšega meseca pod $10^{\circ} \mathrm{C}(\mathrm{Og}$ rin D., 1996). Značilna je velika namočenost (od 1800 do $2600 \mathrm{~mm}$ padavin letno) z zmerno sredozemskim padavinskim režimom. Primarni višek padavin je $\mathrm{v}$ jeseni (november), sekundarni zgodaj poleti (junij), najmanj padavin je običajno konec zime in $\mathrm{v}$ začetku pomladi. Jezersko je redko poseljeno, osrednje naselje je Zgornje Jezersko (560 prebivalcev; SURS, 2015). Poselitev je zgoščena ob jugozahodnem, bolj osončenem robu kotlinice, višje so le posamezne domačije. Gozd pokriva dobrih $76 \%$ obravnavanega območja, površin z redkim ali brez rastlinstva je dobrih $13 \%$, slabih $10 \%$ predstavljajo travišča in grmišča, manj kot $1 \%$ je pozidanih površin.

Slika 2: Ravenska Kočna (foto: D. Ogrin).

Figure 2: Ravenska Kočna (photo: D. Ogrin).

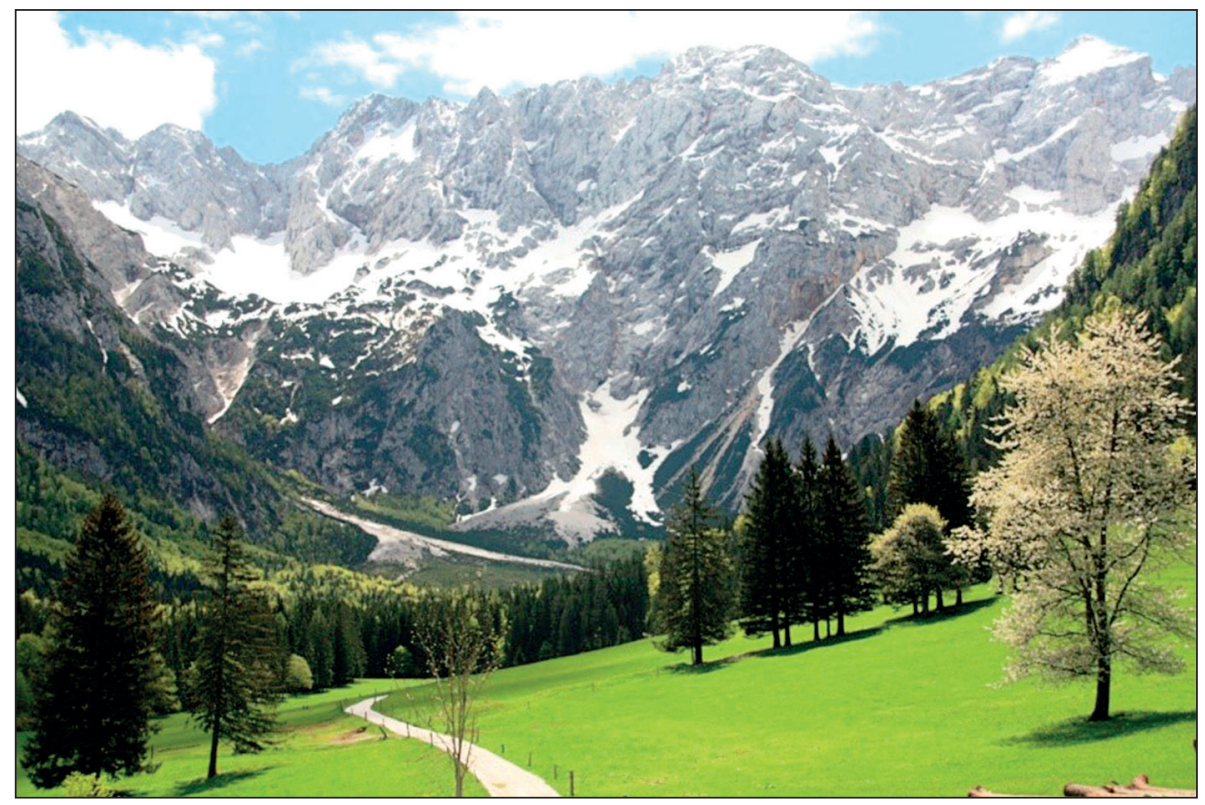




\section{LOKALNO IN MIKRO PODNEBJE JEZERSKEGA}

Pri opredeljevanju lokalnega podnebja so osnovnega pomena reliefne značilnosti površja, kot so višinska struktura, tip površja (konveksne, konkavne oblike), usmerjenost in naklon pobočij, prisotnost vodnih površin in vlažnost tal, raba tal ipd. Ti dejavniki vplivajo na razlike $\mathrm{v}$ insolaciji, na temperaturne in padavinske razmere ter na pojav lokalnih vetrov. Na mikroravni, ki jo opredeljujemo s prostorskimi enotami najnižje ravni (od nekaj $\mathrm{m}^{2}$ ali $\mathrm{m}^{3}$, če upoštevamo še ozračje neposredno nad njimi, do nekaj $\mathrm{km}^{2}$ ali $\mathrm{km}^{3}$ ), prostori, ki nimajo geografskih dimenzij (jama, soba), ali kot podnebje v rastlinski odeji, imajo še poseben pomen tip vegetacije in rabe tal ter vlažnostne razmere v tleh.

\section{I Lokalne razlike $v$ osončenosti}

Na lokalne in mikro razlike v Sončevem obsevanju in prejeti energiji Sončevega sevanja vplivajo višina južnega obzorja oziroma zasenčenost zaradi njega, ekspozicija in naklon površja. V naših geografskih širinah so z vidika povprečnih razmer ugodne južne ekspozicije z nakloni okoli $45^{\circ}$. Razlike v prejeti energiji Sončevega sevanja med posameznimi ekspozicijami so veliko večje pozimi, ko je sonce nizko nad horizontom in je čas obsevanja krajši kakor pa poleti.

Jezersko ima zelo razgibano površje z velikimi relativnimi višinskimi razlikami, zato so tudi lokalne razlike v obsijanosti in prejeti energiji Sončevega sevanja velike. Zaradi visokega južnega obzorja se razmere zelo spreminjajo tudi med letom. Glede na aprilske razmere, ki so dober kazalec povprečnih razmer (slika 6), so dobro obsijana strmejša pobočja z južno, jugovzhodno in jugozahodno ekspozicijo pod Karavankami in jugozahodna pobočja grebena med Skubrovim vrhom (1276 m) in Špegovcem (1619 m) nad Makekovo Kočno. Po slabi obsijanosti izstopajo strma, severno usmerjena pobočja Kamniško-Savinjskih Alp pod grebenom med Velikim vrhom (1742 m), Oltarji, Jezersko Kočno $(2540 \mathrm{~m})$ in Grintovcem $(2558 \mathrm{~m})$, osoje globoke in ozke doline Jezernice pri Spodnjem kraju, severna in severovzhodna pobočja med Skubrovim vrhom in Špegovcem nad Ravensko Kočno ter posamezne globoke in ozke grape v Karavankah. Okoli poletnega obrata, ko je Sonce najvišje nad ravnino horizonta, je velika večina obravnavane pokrajine dobro obsijana s soncem (slika 3 b). Slabše obsijani so le predeli, ki imajo zelo visok južni horizont. Med njimi so severna pobočja pod grebenom med Velikim vrhom in Grintovcem, osoje Ravenske Kočne in doline Kokre ter Jezernice med Kanonirjem in Spodnjim krajem. Okoli zimskega obrata prevladuje slaba obsijanost s soncem. Bolje so obsijana in več energije Sončevega sevanja dobijo le prisojna pobočja pod Karavankami in nad Makekovo Kočno (slika 3 a).

Glede na meritve poteka realnega obzorja in primerjavo z navideznimi potmi sonca nad ravnino obzorja imajo dobro obsijana južno usmerjena pobočja Karavank nad Jezersko kotlinico okoli zimskega obrata teoretično 4 do 5 ur s soncem (3 do 4 manj od teoretično možnega), okoli poletnega obrata pa 10 do 13 ur (3 do 6 ur manj od teoretično možnega). V najslabše obsijanih predelih, ki imajo zelo visoko južno obzorje, pa so okoli zimskega obrata, ko je Sonce nizko nad obzorjem, tudi brez neposrednega Sončevega 
Slika 3: Prejeta energija Sončevega sevanja na Jezerskem januarja (a) in junija (b). Figure 3: Energy of solar radiation at Jezersko in January (a) and June (b).

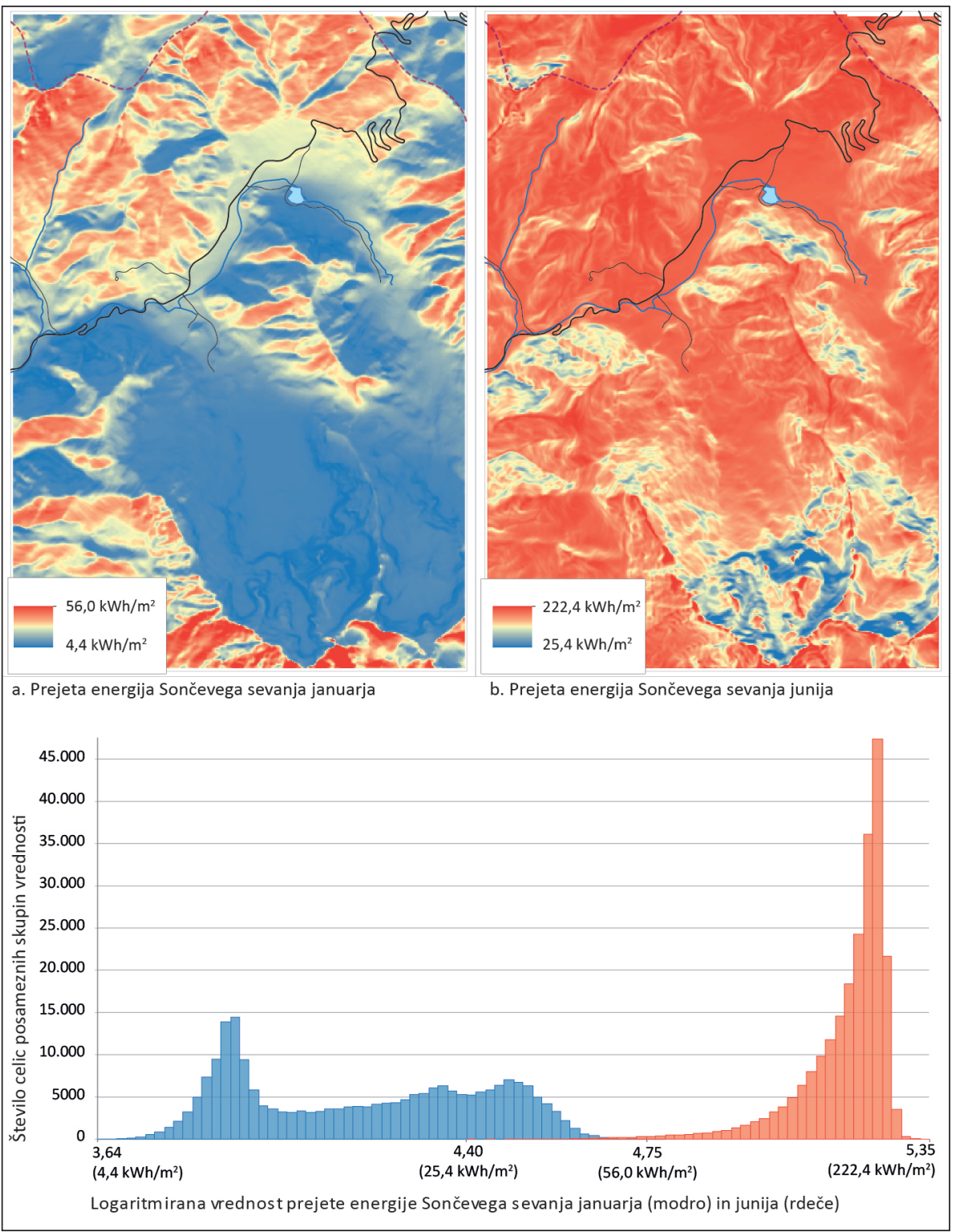


obsevanja. Med njimi so tudi nekatere domačije, kakor Ancelj in Sušnik v Ravenski Kočni. Okoli poletnega obrata jim okoliški grebeni skrajšujejo teoretično možno Sončevo sevanje za 6 do 7 ur.

Po izračunih orodja Solar Radiation programskega paketa ArcGIS prejmejo najbolje obsijani predeli Jezerskega v povprečju okoli $1660 \mathrm{kWhm}^{-2}$ Sončeve energije na leto, najslabše obsijani pa le okoli $190 \mathrm{kWhm}^{-2}$. Večina obravnavane pokrajine (66\%) dobi med 800 in $1300 \mathrm{kWhm}^{-2}$ letno (srednje obsijani predeli), po okoli $17 \%$ pa od 190 do 800 $\mathrm{kWhm}^{-2}$ (slabo obsijani predeli), oziroma 1300 do $1660 \mathrm{kWhm}^{-2}$ (dobro obsijani predeli). V srednje (97 \%) in v dobro obsijanih predelih (3\%) živijo tudi vsi prebivalci Jezerskega. Za primerjavo, povprečno letno obsevanje na horizontalno površino v Sloveniji je 1250 $\mathrm{kWhm}^{-2}$ (Kastelec in sod., 2007; Sončno sevanje in obsevanje, 2016).

Razmerje med slabo, srednje in dobro obsijanimi predeli se med letom zelo spreminja. Če za povprečno stanje vzamemo aprilske razmere, potem ima januarja celotno obravnavano območje slabe razmere, junija pa je skoraj $83 \%$ pokrajine dobro obsijane (preglednica 1).

Preglednica 1: Deleži površja po razredih prejete povprečne mesečne energije Sončevega sevanja. Table 1: Percentages of surface by classes of the received average monthly solar radiation.

\begin{tabular}{|l|c|c|c|}
\cline { 2 - 4 } \multicolumn{1}{c|}{} & Januar & April & Junij \\
\hline $\begin{array}{l}\text { Slabo obsijani predeli } \\
\left(\text { pod } 86,6 \mathrm{kWhm}^{-2}\right)\end{array}$ & $100 \%$ & $16,3 \%$ & $1,7 \%$ \\
\hline $\begin{array}{l}\text { Srednje obsijani predeli } \\
\left(86,6-142,8 \mathrm{kWhm}^{-2}\right)\end{array}$ & $0 \%$ & $69,7 \%$ & $15,7 \%$ \\
\hline $\begin{array}{l}\text { Dobro obsijani predeli } \\
\left(\text { nad } 142,8 \mathrm{kWhm}^{-2}\right)\end{array}$ & $0 \%$ & $14,0 \%$ & $82,6 \%$ \\
\hline
\end{tabular}

\subsection{Vpliv površja na temperaturo zraka}

Lokalne razlike $\mathrm{v}$ prostorski razporeditvi temperature zraka so odvisne od reliefnih danosti, na mikroravni tudi od vlažnosti in rabe tal ter prisotnosti snežne odeje. Primarna značilnost razporejanja temperature zraka na mikroravni je velika dnevna temperaturna amplituda med zgornjo plastjo tal in površjem v primerjavi s temperaturo zraka v prizemni plasti ozračja, npr. na višini $2 \mathrm{~m}$, na kateri se standardno meri temperatura zraka. Razlike so lahko tudi 10 do $15^{\circ} \mathrm{C}$. Vlažna, ilovnata tla se $\mathrm{v}$ dnevnem ciklu počasneje in manj segrejejo; suha, peščena tla pa se hitreje segrejejo in tudi ohladijo. Če je površje pokrito s snežno odejo, so zimske temperature zraka lahko tudi za 5 do $10^{\circ} \mathrm{C}$ nižje (Barry, Hall-McKim, 2014), ker je sneg dober izolator in preprečuje tok toplote iz tal, hkrati ima zelo velik albedo in je dober sevalec dolgovalovnega sevanja.

Za obravnavano pokrajino je značilno zelo razgibano površje z velikimi relativnimi višinskimi razlikami in dolgimi ter strmimi pobočji ter prisotnost izrazitih konkavnih in konveksnih oblik površja. Z naraščajočo nadmorsko višino se temperatura zraka na splošno znižuje (povečuje se količina padavin), konkavni deli površja imajo ob radiacijskem 
vremenu nižje minimalne temperature zaradi temperaturnega obrata. Južno orientirana pobočja so zaradi več prejete energije Sončevega sevanja toplejša od severnih. Gozd ima bolj izravnan temperaturni režim (še zlasti listopadni v topli polovici leta) kot negozdne, travnate ali neporaščene (slabo poraščene) površine.

\subsection{Zniževanje temperature zraka z nadmorsko višino}

Po karti Letne povprečne temperature zraka za obdobje 1981-2010 (2016), ki je narejena $\mathrm{z}$ metodo optimalne prostorske interpolacije in upošteva povezanost spremenljivke $\mathrm{z}$ nadmorsko višino in preko okolice tudi mikrolokacijo ter ima prostorsko ločljivost $100 \mathrm{x}$ $100 \mathrm{~m}$, je povprečna letna temperatura zraka ob zgornji Kokri in v Jezerski kotlinici med 6 in $7{ }^{\circ} \mathrm{C}$, na grebenih Karavank 4 do $6{ }^{\circ} \mathrm{C}$ in na najvišjih grebenih Kamniško-Savinjskih Alp 0 do $2{ }^{\circ} \mathrm{C}$. Povprečne januarske temperature so ob zgornji Kokri in v Jezerski kotlinici med -2 in $-4{ }^{\circ} \mathrm{C}$ in na grebenih Kamniško-Savinjskih Alp pod -4 (Januarska povprečna temperatura zraka, obdobje 1981-2010, 2016). Julijske temperature so v Jezerski kotlinici od 14 do $16{ }^{\circ} \mathrm{C}$, na grebenih Karavank okoli $12-14{ }^{\circ} \mathrm{C}$ in na najvišjih vrhovih KamniškoSavinjskih Alp 8-10 ${ }^{\circ} \mathrm{C}$ (Julijska povprečna temperatura zraka, obdobje 1981-2010, 2016). Iz teh podatkov znaša ocenjen vertikalni temperaturni gradient za povprečno letno temperaturo zraka okoli $-0,44{ }^{\circ} \mathrm{C} / 100 \mathrm{~m}$, za povprečno julijsko temperaturo $-0,5{ }^{\circ} \mathrm{C} / 100 \mathrm{~m}$ in za povprečno januarsko $-0,37^{\circ} \mathrm{C} / 100 \mathrm{~m}$. Po podatkih za meteorološko postajo Zgornje Jezersko (n. v. 894 m) za obdobje 1961-1990 je bila povprečna letna temperatura zraka $5,9{ }^{\circ} \mathrm{C}$, povprečna januarska $-3,1^{\circ} \mathrm{C}$ in julijska $15,0^{\circ} \mathrm{C}$ (Klimatografija Slovenije, temperatura zraka, obdobje 1961-1990, 1995; preglednica 2). Če upoštevamo trende segrevanja ozračja v zadnjih dveh desetletjih, ugotovimo, da so povprečne temperature na Jezerskem za okoli $2{ }^{\circ} \mathrm{C}$ nižje kot v Ljubljanski kotlini v okolici Preddvora.

Preglednica 2: Povprečne mesečne, sezonske in letne temperature zraka $\left(v^{\circ} \mathrm{C}\right)$ za meteorološki postaji Zgornje Jezersko (n. v. 894 m, 1961-1990) in Preddvor (n. v. 485 m, 1992-2011).

Table 2: Average monthly, seasonal and annual air temperatures (in ${ }^{\circ} \mathrm{C}$ ) at the meteorological stations of Zgornje Jezersko (894 $m$ a.s.l.; 1961-1990) and Preddvor (485 m a.s.l.; 1992-2011).

\begin{tabular}{|l|c|c|c|c|c|c|c|c|c|c|c|c|}
\cline { 2 - 12 } \multicolumn{1}{c|}{} & I & \multicolumn{1}{c|}{ II } & III & IV & V & VI & VII & VIII & IX & X & XI & XII \\
\hline Zg. Jezersko & $-3,1$ & $-1,6$ & 1,1 & 5,0 & 9,9 & 13,2 & 15,0 & 14,1 & 11,0 & 6,7 & 1,7 & $-2,1$ \\
\hline Preddvor & $-0,3$ & 1,4 & 5,1 & 9,7 & 14,7 & 17,9 & 19,5 & 19,0 & 14,1 & 10,1 & 4,9 & 0,1 \\
\hline
\end{tabular}

\begin{tabular}{|l|l|l|l|l|l|}
\cline { 2 - 6 } \multicolumn{1}{c|}{} & Zima & Pom. & Pol. & Jes. & \multicolumn{1}{c|}{ Leto } \\
\hline Zg. Jezersko & $-2,2$ & 5,3 & 14,1 & 6,5 & 5,9 \\
\hline Preddvor & 0,4 & 9,8 & 18,8 & 9,7 & 9,6 \\
\hline
\end{tabular}

Viri podatkov/Source: Klimatogeografija Slovenije, temperatura zraka, 1995 (Zg. Jezersko, str. 134); Arhiv meteoroloških podatkov ARSO, 2016 (Preddvor). 
Omenjeni podatki dajejo zelo grobo sliko razporejanja temperature zraka z višino tudi zato, ker je na širšem območju Jezerskega mreža uradnih temperaturnih postaj zelo redka. Da bi dobili dodaten vpogled $\mathrm{v}$ lokalne razmere, smo v drugi polovici maja $\mathrm{v}$ obdobju 2013-2015 opravili več meritev temperature zraka na profilih od dna doline po pobočjih navzgor. Vertikalni temperaturni gradienti so bili ob meritvah z digitalnim termometrom različni, odvisni od vremenskih razmer, poraščenosti profila in časa meritev. Ob jutranjih meritvah ob radiacijskem vremenu pred sončnim vzhodom so pokazali na inverzna temperaturna stanja pri tleh, ob meritvah čez dan pa običajno razporejanje temperature zraka z višino. 16. maja 2013, med 9. in 10. uro dopoldan, je bil vertikalni temperaturni gradient ob popolnoma oblačnem vremenu, ob poti z Zgornjega Jezerskega (n. v. $880 \mathrm{~m}$ ) po planinski poti proti Virnikovemu Grintovcu do n. v. $1160 \mathrm{~m}$ nad samotno kmetijo Murn, $-0,87^{\circ} \mathrm{C} / 100$, na nasprotni strani doline pa po Makekovi Kočni do n. v. 1410 m na Prodih pod Oltarji $-0,84{ }^{\circ} \mathrm{C} / 100$. Enak gradient je bil tudi 27. 5. 2015 med Zgornjim Jezerskim in vrhom Virnikovega Grintovca (n. v. $1654 \mathrm{~m}$ ) sredi dopoldneva ob labilnem ozračju in vetrovnem vremenu. Manjši gradient, $-0,57^{\circ} \mathrm{C} / 100 \mathrm{~m}$, smo s pomočjo regresijske premice izračunali 25. 5. 2015 okoli poldneva med Makekovo Kočno in Prodi, ko smo meritve opravljali samo v gozdu. Vertikalne temperaturne gradiente $-0,84^{\circ} \mathrm{C} / 100 \mathrm{~m}$ je izračunala tudi Pintarjeva (2015), ko je pozimi, 12. februarja 2015, ob oblačnem vremenu merila temperaturo zraka na profilu od Spodnjega Jezerskega (n. v. 825 m) do Jezerskega vrha (n. v. $1218 \mathrm{~m}$ ).

\subsubsection{Temperaturni obrat $v$ Jezerski kotlinici}

$\mathrm{Ob}$ radiacijskem tipu vremena (oblačnost manjša od $2 / 10$, povprečna hitrost vetra manjša od $4 \mathrm{~m} / \mathrm{s}$ ) se v nočnem času v konkavnih reliefnih oblikah razvije temperaturni obrat. Konkavno površje omogoča zbiranje in nadaljnje ohlajanje hladnega, gostejšega zraka, ki se z okoliških pobočij steka v kotlino in doline. Nastane jezero hladnega zraka, ki je do konca noči lahko globoko tudi več sto metrov. Zgornja meja temperaturnega obrata je običajno na približno $1 / 5$ do $1 / 4$ relativne višine reliefa nad dnom doline oziroma kotline. Zjutraj se pobočja ogrejejo, ogreti zrak se meša v smeri zgornje meje inverzne plasti, kar inverzno plast tanjša, dokler se zrak popolnoma ne premeša (Barry, Hall-McKim, 2014). Zaradi tega je podnebje $\mathrm{v}$ dnu konkavnih oblik reliefa drugačno od lokalnega podnebja nad temperaturnim obratom. Ponoči in zjutraj so temperature nižje, več je brezvetrja, zrak je bolj vlažen, več je megle in kondenzacijskih pojavov na tleh (rose, slane), razen tega je v hladnem delu leta zaradi pogostejše megle trajanje Sončevega obsevanja krajše.

Maršrutne profilne meritve uro pred sončnim vzhodom meseca maja po dnu Jezerske kotlinice in njenem obodu, po Makekovi in Ravenski Kočni ter po cesti na prelaz Jezerski vrh $(1218 \mathrm{~m})$ so pokazale relativno plitvo inverzno plast zraka. To ni presenetljivo, saj Jezerska kotlinica nima sklenjenega oboda in ima odtok proti dolini Kokre, kamor lahko odteka hladen zrak. Glede na meritve in opazovanja hladen zrak še najbolj zastaja na Ravnah med Planšarskim jezerom in Lustigom ter v posameznih plitvih kotanjah. 14. maja 2013 je bila inverzna plast zraka debela okoli $200 \mathrm{~m}$. Najnižje temperature (med 1,5 in 
$2{ }^{\circ} \mathrm{C}$ ) so bile na polju pod cerkvijo Sv. Andreja in Planšarskim jezerom (n. v. okoli $895 \mathrm{~m}$ ) ter v plitvi kotanji jugovzhodno od domačije Ancelj (n. v. 960 m), le nekoliko višje, do $2,5^{\circ} \mathrm{C}$, tudi v preostalem delu kotlinice med Ravnami in Zgornjim Jezerskim. Najvišje (okoli $5,5^{\circ} \mathrm{C}$ ) smo namerili na pobočju v višinskem pasu med 990 in $1110 \mathrm{~m}$, višje so se začele rahlo zniževati. Intenziteta temperaturnega obrata je znašala okoli $3,5^{\circ} \mathrm{C}$ (slika 4). Podobna razporeditev je bila tudi naslednji dan, 15. maja 2013. 28. maja 2015 je bila inverzna plast zraka plitvejša, le okoli $30 \mathrm{~m}$. V njej smo namerili 3 do $4{ }^{\circ} \mathrm{C}$, najmanj $\left(2,5^{\circ} \mathrm{C}\right)$ v kotanji pri domačiji Ancelj. Na Ravnah je bil zelo dobro izražen toplotni pas v višinah med 930 in $1000 \mathrm{~m}, \mathrm{~s}$ temperaturo zraka okoli $6{ }^{\circ} \mathrm{C}$. Višje so se temperature spustile do $3,7^{\circ} \mathrm{C}$, kolikor smo namerili na Jezerskem vrhu. Temperatura zraka na višini okoli $1200 \mathrm{~m}$ je bila torej podobna kot $\mathrm{v}$ dnu kotlinice na nadmorski višini okoli $900 \mathrm{~m}$.

V evropskih sredogorjih, npr. v Vogezih in Juri, kjer so relativne višine med dnom dolin in vrhovi okoli $500 \mathrm{~m}$, se toplotni pas običajno pojavlja 100 do $400 \mathrm{~m}$ nad dnom; v Alpah, kjer so relativne višine večje, se poleti začne približno $350 \mathrm{~m}$ nad dnom, pozimi pa okoli 700 m nad dnom dolin (Barry, Hall-Mc Kim, 2014). Iz raziskav Gamsa (1996), Žiberne (1999) in D. Ogrina (2000) izhaja, da je orientacijska zgornja meja termalnega

Slika 4: Temperaturni obrat na Jezerskem 14. 5. 2013, od 5.08 do 6.02.

Figure 4: Temperature inversion at Jezersko on 14 May 2013, from 05:08 to 06:02.

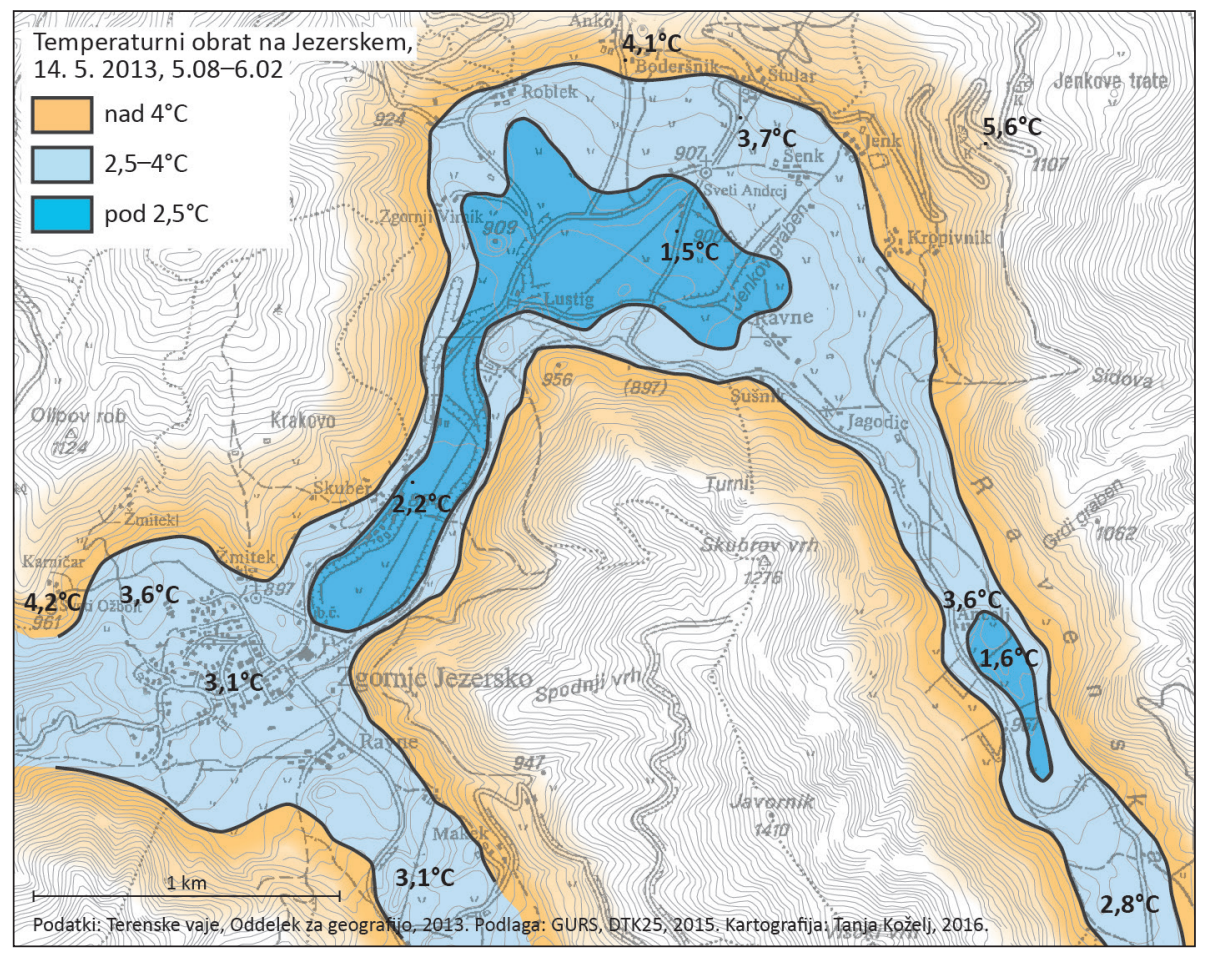


pasu pri nas med 200 in 500 m relativne višine, spodnja v vinogradniških predelih vzhodne Slovenije in oljkarskih Slovenske Istre pa med 10 in 40 m (Žiberna, 1992; Ogrin D., Mužina, 2005; Ogrin D., 2007). Po naših meritvah na Jezerskem se je termalni pas začel od 30 do okoli $200 \mathrm{~m}$ nad dnom kotlinice.

Meritve ob stabilnih vremenskih razmerah pozimi so pokazale podobno razporeditev temperature zraka kot v topli polovici leta. Kljub relativno visoki nadmorski višini, tudi ob prisotnosti snežne odeje, se na Jezerskem ne more pretirano ohladiti, ker zrak odteka po dolini Jezernice v dolino Kokre. Po ugotovitvah Pintarjeve (2015) prevladujejo tudi v tem letnem času plitve inverzije $\mathrm{z}$ intenziteto 5 do $6{ }^{\circ} \mathrm{C}$. Glede na meritve 8 . marca 2015 je bilo jezero hladnega zraka debelo okoli $100 \mathrm{~m}$, intenziteta temperaturnega obrata pa $6^{\circ} \mathrm{C}$. Z razliko od tople polovice leta pa po nizkih temperaturah izrazito odstopajo plitve kotanje v pozimi zelo slabo osončenih Kočnah, kakor je kotanja pri kmetiji Ancelj v Ravenski in kotanja pod kmetijo Makek v Makekovi Kočni. Tu je bila temperatura zraka 8. 3. 2015 med 5.20 in 6.07 okoli $-6^{\circ} \mathrm{C}$, v ostalih konkavnih predelih Jezerskega pa okoli $-4{ }^{\circ} \mathrm{C}$. Najtoplejši predeli, kakih $100 \mathrm{~m}$ nad dnom kotlinice, so imeli temperaturo okoli $0{ }^{\circ} \mathrm{C}$, na Jezerskem vrhu pa je bilo $-4,2{ }^{\circ} \mathrm{C}$ (Pintar, 2015).

\subsubsection{Vršni poganjki pri drevesih kot odraz lokalnih temperaturnih in ras- tiščnih razmer}

Praviloma se fenofaze pri rastlinah začnejo prej tam, kjer je topleje. V maju, ko se rastna sezona začne tudi v alpskih dolinah in kotlinah, smo v obdobju 2013-2015 ugotavljali, ali so lokalne temperature razlike na Jezerskem dovolj velike, da so opazne tudi v dolžini vršnih poganjkov dreves. Poganjke smo merili pri 1,5 do $3 \mathrm{~m}$ visokih smrekah in bukvah v dolini Kokre pri Spodnjem kraju, v Makekovi in Ravenski Kočni ter v Jezerski kotlinici in pobočjih nad njo. Meritve smo opravili na 43 lokacijah z različno nadmorsko višino in lego. Na vsaki lokaciji smo izmerili od 20 do 30 bolj na samem rastočih dreves, ki so rastla v vsaj približno primerljivih razmerah in nato izračunali povprečne vrednosti prirastkov tekoče sezone za lokacije in nekatere mere variabilnosti.

Rezultati meritev so pokazali na kompleksen odnos med višinskim prirastom in lokalnimi rastiščnimi (podnebnimi) razmerami, bistveno bolj kot v primeru podobne raziskave v Planici (Ogrin D., Krevs, 1995). Pri primerjavi posameznih lokacij z razliko v nadmorski višini 200 do $300 \mathrm{~m}$ in enako ekspozicijo, razlik v dolžini vršnih poganjkov praktično ni bilo ali so bile neznačilne (npr. 13. 5. 2013 na profilu Makek, 970 m, - Skubrov vrh, 1200 m; 15. 5. 2014 profil po Makekovi Kočni, 900 do 1150 m). Pogosti so bili tudi primeri, ko so bile razlike pri bukvi značilne, pri smreki pa ne (npr. 13. 5. 2013 na profilu Spodnji kraj, 765 m, - Zgornje Jezersko, 905 m; 15. 5. 2014 na profilu Ravne, 900 m, - Žarkovo, 1100 m). Pojasnilo iščemo v različnih začetkih rastne sezone, saj je sredi maja, ko smo opravljali meritve, smreka šele začela odganjati, bukev pa je z rastno sezono začela nekoliko prej.

V precejšnjem številu primerov smo odkrili najbolj pričakovan odnos, da so vršni poganjki z višino, ob enaki ekspoziciji, vse manjši (npr. 13. 5. 2013 za bukev na profilu Spodnji kraj, 765 m - Zgornje Jezersko, 905 m; za smreko in bukev na profilih Ancelj, 
$970 \mathrm{~m}$ - Štularjeva planina, $1275 \mathrm{~m}$ in Zgornje Jezersko, $905 \mathrm{~m}$ - Olipov vrh, $1060 \mathrm{~m}$; 15. 5. 2014 na profilu Makek, $990 \mathrm{~m}$ - Štularjeva planina, $1405 \mathrm{~m} ; 26.5 .2015$ na profilu Zgornje Jezersko, 940 m - Skubrov vrh, 1100 m idr.). Dolžina terminalnih poganjkov se je z višino bolj zmanjševala pri bukvi, ki začne prej z rastjo (vertikalni gradienti priraščanja med $-1,4$ in $-4 \mathrm{~cm} / 100 \mathrm{~m}$ ), še posebej v najnižjih delih raziskovalnega območja (Spodnji kraj-Zgornje Jezersko: $-8,9 \mathrm{~cm} / 100 \mathrm{~m}$ ). Manj pa pri smreki (vertikalni gradienti priraščanja med $-0,3$ in $-2,1 \mathrm{~cm} / 100 \mathrm{~m}$ ), ki je v času meritev v nižjih predelih Jezerskega šele dobro začela $z$ rastjo, v višjih nadmorskih višinah pa še ni odgnala. 15. maja 2014 je npr. smreka na Skubrovem vrhu odgnala do nadmorske višine okoli 1100 m, bukev pa do okoli $1250 \mathrm{~m}$.

Potrditev teze, da se kljub specifičnim lokalnim rastiščnim razmeram višinski prirast z višino manjša, smo dobili pri opazovanju dolžine terminalnih poganjkov pri bukvi in smreki na profilu od Raven (okoli 900 m) in Ravenske Kočne (900 do 1100 m) do okolice Češke koče na Spodnjih Ravneh (1420 do 1570 m). Terminalne poganjke smo merili 6. 8. 2015, ko je višinski prirast zaključen. Tudi v tem primeru so se vršni poganjki z višino bolj zniževali pri bukvi $(-2,7 \mathrm{~cm} / 100 \mathrm{~m})$ kot pri smreki $(-2,5 \mathrm{~cm} / 100 \mathrm{~m})$, čeprav razlika ni značilna. Pri bukvah na dnu Ravenske Kočne, ne glede na nadmorsko višino, ni bilo bistvenih razlik v povprečni dolžini vršnih poganjkov (preglednica 3).

Preglednica 3: Dolžina vršnih poganjkov smreke in bukve (v cm) 6. 8. 2015 na profilu od Raven in Ravenske Kočne do Zgornjih Raven.

Table 3: The length of terminal increments of spruce and beech (in cm) on 6 August 2015 along the profile from Ravne and Ravenska Kočna to Zgornje Ravne.

\begin{tabular}{|l|r|r|r|r|r|r|r|r|r|r|}
\cline { 2 - 11 } \multicolumn{1}{c|}{} & \multicolumn{4}{c|}{ Smreka } & \multicolumn{5}{c|}{ Bukev } \\
\hline Lokacija vzorčenja & Povp. & Min. & Maks. & SD & N & Povp. & Min. & Maks. & SD & N \\
\hline $\begin{array}{l}\text { Ravne-Ancelj } \\
(900-1010 \text { m) }\end{array}$ & 33,5 & 19 & 47 & 9,1 & 30 & 30,2 & 12 & 43 & 7,8 & 29 \\
\hline $\begin{array}{l}\text { Parkirišče } \\
(1020-1060 \text { m) }\end{array}$ & 24,2 & 10 & 43 & 8,4 & 24 & 32,0 & 16 & 40 & 6,6 & 32 \\
\hline $\begin{array}{l}\text { Vojtrca-Zg. } \text { Ravne } \\
(1540-1570 \text { m) }\end{array}$ & 17,7 & 6 & 40 & 6,8 & 29 & 16,3 & 3 & 29 & 5,9 & 29 \\
\hline
\end{tabular}

Povp. - povprečna dolžina; Min. - najkrajši poganjek, Maks. - najdaljši poganjek; SD - standardni odklon; $N$-numerus.

Zaradi velikih razlik v osončenosti in posledično v temperaturi zraka med izrazitimi prisojami in osojami smo sredi maja pričakovali tudi značilne razlike v dolžini vršnih poganjkov med obema legama. Zaradi težav z iskanjem lokacij s primerljivimi ostalimi rastiščnimi pogoji lahko to tezo potrdimo le na dveh primerih. Smreke v izrazitih osojah Makekove Kočne sredi maja 2013 še niso odgnale, medtem ko so imele na primerljivi nadmorski višini v prisojah do $2 \mathrm{~cm}$ dolge poganjke. Pri bukvi je znašala povprečna dolžina terminalnih poganjkov v osojah $6 \mathrm{~cm}$, v prisojah pa $10 \mathrm{~cm}$. Značilno razliko smo opazili tudi pri smrekah 15. 5. 2014 med okolico kmetije Anko, ki leži na izraziti prisojni 
legi, in okolico Planšarskega jezera. Pri Anku so bili vršni poganjki v povprečju dolgi $4,1 \mathrm{~cm}$, v osojah Planšarskega jezera pa $3,2 \mathrm{~cm}$. Na pomen ekspozicije in osončenosti za začetek rastne sezone lahko sklepamo tudi iz nadmorske višine, do katere so drevesa odgnala. 15. 5. 2014 so smreke na prisojah nad Jezersko kotlinico odgnale do nadmorske višine okoli $1200 \mathrm{~m}$, v osojah pa do 900-1050 m.

Pri opazovanju sprememb dolžine terminalnih poganjkov na profilih od dna Jezerske kotlinice po njenih prisojnih pobočjih smo pogosto opazili pojav obrata v priraščanju. $\mathrm{V}$ dnu kotlinice je bil pri bukvi prirast manjši oziroma se je pri smreki šele začel ali pa še to ne, največji je bil 100 do $200 \mathrm{~m}$ nad dnom, nato se je začel z višino zmanjševati. Za ilustracijo: po meritvah 26. 5. 2015 na vsakih $50 \mathrm{~m}$ višinske razlike na profilu od Zgornjega Jezerskega (okoli $950 \mathrm{~m}$ n. v.) do Žmitkovega vrha (1238 m) so bili smrekovi poganjki ob dnu kotlinice v povprečju dolgi okoli $1,5 \mathrm{~cm}$, na nadmorski višini okoli $1080 \mathrm{~m}$ skoraj $3 \mathrm{~cm}$, pri okoli $1200 \mathrm{~m}$ pa spet okoli $1 \mathrm{~cm}$ (slika 5). Inverzno razporeditev razlagamo s pojavom temperaturnega obrata in nižjimi minimalnimi temperaturami $\mathrm{v}$ dnu kotlinice, ki se jim pridružujejo še nekoliko slabše razmere v osončenosti in toplejšimi razmerami $\mathrm{z}$ več sonca $\mathrm{v}$ prisojah oboda kotlinice.

Slika 5: Dolžina vršnih poganjkov smreke 26. 5. 2015 na profilu od Zgornjega Jezerskega do Žmitkovega vrha.

Figure 5: The length of terminal increments of spruce on 26 May 2015 along the profile from Zgornje Jezersko to Žmitkov vrh.

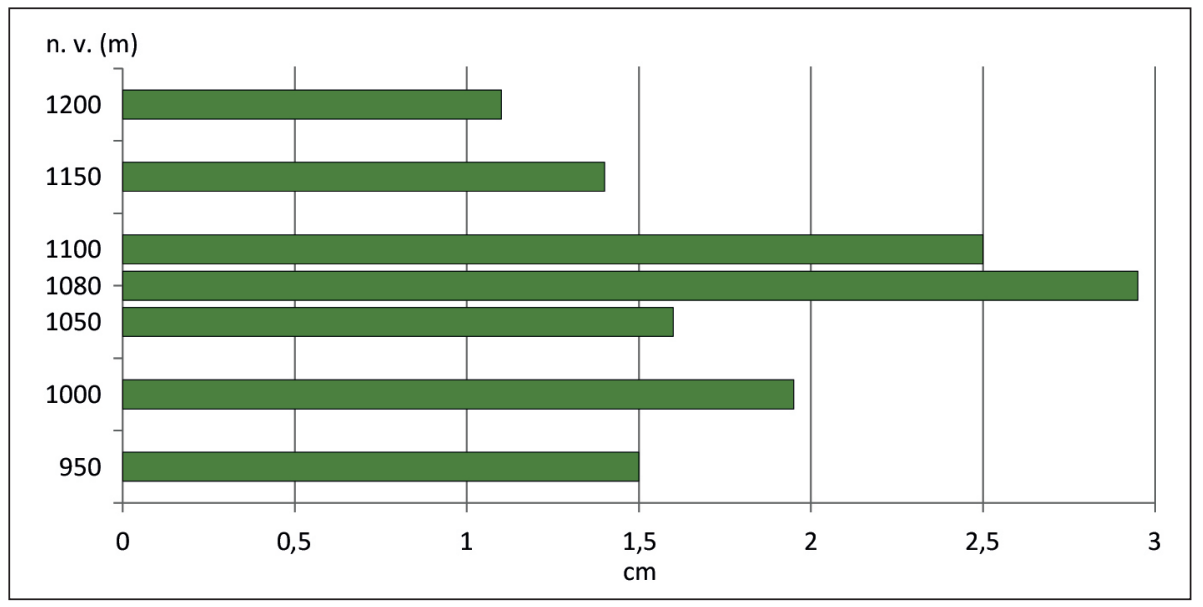

\subsection{Lokalni vetrovi}

Na grebenih Kamniško-Savinjskih Alp (in verjetno tudi Karavank) prevladujejo, glede na podatke za Krvavec (n. v. 1740 m; 1991-2009), severozahodni, severni in 
vzhodni vetrovi, ki dosegajo po modelu Aiolos povprečne letne hitrosti $10 \mathrm{~m}$ nad tlemi od 4 do 6 m/s (Rakovec in sod. 2009, str. 102). Vetrovi so močnejši na sedlih in v drugih vrzelih gorskih pregrad. Sama Jezerska kotlinica je slabše prevetrena. Po podatkih za meteorološko postajo Zgornje Jezersko (n. v. 894 m; 1961-1984) je delež brezvetrja kar $48 \%$; če je vetrovno, pa prevladujeta severovzhodnik in jugozahodnik, ki sledita usmerjenosti reliefa. Močnejši vetrovi so pogostejši ob spremembah vremena, povezani so s prehodi vremenskih front, ciklonov in ciklogenezo v severnem Sredozemlju. Časovno in prostorsko so omejeni, spremljajo lahko tudi nevihte. Velike hitrosti lahko ob južnem vznožju Karavank doseže tudi severni fen (karavanški fen, karavanška burja). Močnejši severni fen se v povprečju pojavlja enkrat do dvakrat letno, večinoma v hladni polovici leta, in dosega hitrosti in sunkovitost burje. Nastane ob splošnih severnih ali severozahodnih vetrovih nad nami, ko se zrak pretaka čez Alpe. V sunkih lahko doseže hitrosti tudi nad $20 \mathrm{~m} / \mathrm{s}$ in podira drevje, odkriva strehe ipd. Zaradi stekanja zraka je najmočnejši v dolinah, ki so pravokotne na gorske grebene, med njimi tudi v dolini Kokre in na Jezerskem.

Lokalni vetrovi so rezultat horizontalnih in vertikalnih razlik v temperaturi ter posledično gostoti zraka. Pihajo, ko so splošni vetrovi šibki, ali jih ni in ko je nebo jasno. Ponoči se pojavljajo spuščajoči (katabatski) vetrovi (gornik), ko se hladen, gostejši zrak spušča po pobočjih $\mathrm{v}$ doline, toplejši dolinski zrak pa tvori povratni tok proti gorskim grebenom. Podnevi piha anabatski veter (dolnik) ob ogretih pobočjih proti vrhovom gora, v višinah nekaj $100 \mathrm{~m}$ pa poteka povratni tok nad dolino, ki zaključuje lokalno kroženje zraka. Če je dvigajoči zrak dovolj vlažen, nastanejo pri dviganju nad grebene kopasti oblaki, ki se lahko ob labilnem ozračju poleti razvijejo v nevihte. Dnevni in nočni vetrovni sistemi prehajajo iz enega $\mathrm{v}$ drugega približno eno uro po sončnem vzhodu in zahodu. Gornik je izrazitejši pozimi, ko so noči dolge, dolnik pa poleti, ko je sonce najmočnejše.

Za spremljanje lokalnih vetrov na Jezerskem v času terenskega dela v maju, v obdobju 2013-2015, ni bilo veliko primernih vremenskih razmer. Kljub temu se da iz meritev $\mathrm{v}$ dneh jasnega in mirnega vremena razbrati osnovne poteze dnevnega hoda vetra. Izrazitejši gornik je pri kraju Zgornje Jezersko začel zvečer pihati po 18. uri in je prenehal med 8. in 9. zjutraj. Zjutraj je dosegal hitrosti do $1 \mathrm{~m} / \mathrm{s}$ (v nočnem času nismo merili). Stekanje hladnega zraka s pobočij je bilo zjutraj izrazitejše v Makekovi in Ravenski Kočni, še posebej v ozkih grapah, kjer so prevladovale hitrosti med 0,5 in 2,2 $\mathrm{m} / \mathrm{s}$, najmočnejši sunki so dosegali do $3,7 \mathrm{~m} / \mathrm{s}$. Zaradi bolj senčne lege je gornik pihal tudi kako uro dlje kot na Zgornjem Jezerskem. Dolnik se je na Zgornjem Jezerskem pojavil med 9. in 10. uro in pihal do okoli 17. ure. Tedaj je začel spreminjati smer iz južne in jugozahodne (po kotlinici navzgor), proti zahodni in severozahodni, oziroma je začel vleči šibek gornik s pobočij Olipovega roba in Žmitkovega vrha. Po 18. uri je spremenil smer v severno oziroma severovzhodno, pihal je vzdolž daljše osi kotlinice navzdol proti dolini Kokre. Hitrosti dolnika so bile večinoma med 2 in 3 m/s, posamezni sunki so sredi dneva dosegli $6 \mathrm{~m} / \mathrm{s}$. Sredi dneva se je nad grebeni Karavank razvila tudi kopasta oblačnost. Na prisojnih pobočjih Makekove in Ravenske Kočne je dolnik pihal s hitrostmi med 0,6 in $4 \mathrm{~m} / \mathrm{s}$. 


\section{TOPOKLIMATSKA KARTA JEZERSKEGA}

Topoklimatska karta Jezerskega (slika 6), ki predstavlja sintezen prikaz lokalnih in tudi nekaterih mikro podnebnih značilnosti, je bila izdelana v merilu $1: 25.000$. Zaradi zelo razgibanega površja merilo ne dopušča prikaza vseh podrobnosti topoklimatskih razmer, zato smo se zaradi boljše preglednosti karte odločili za določeno stopnjo generalizacije elementov površja, ki so pomembni za topoklimo (ekspozicija, naklon, vegetacija, raba tal). Osnovne topoklimatske enote so posledica razlik v nadmorski višini in konkavnosti oziroma konveksnosti površja.

Topoklimo višjega gorskega sveta imajo predeli Kamniško-Savinjskih Alp in Virnikovega Grintovca, ki segajo nad zgornjo gozdno mejo. Termična zgornja gozdna meja je v Kamniško-Savinjskih Alpah po Lovrenčaku (2007) na višini, do katere je povprečna julijska temperatura do okoli $11^{\circ} \mathrm{C}$, to je med 1700 in $1800 \mathrm{~m}$ nadmorske višine. Na severni, osojni in hladnejši strani osrednjega grebena je nižje, med 1500 in $1620 \mathrm{~m}$. Dejansko pa marsikje poteka še nižje zaradi reliefnih in vetrovnih razmer ter posegov človeka. Zgornja gozdna meja, ki smo jo določili s pomočjo evidence gozdnih površin po podatkih gozdnogospodarskih načrtov Zavoda za gozdove Slovenije (Evidenca gozdnih sestojev, 2012), predstavlja zgornjo mejo pojavljanja sklenjenih sestojev gozda. Po teh podatkih je zgornja gozdna meja v obravnavani pokrajini na okoli $1400 \mathrm{~m}$ (na prisojah na okoli 1600 m, na osojah na okoli 1300 m). Topoklimo višjega gorskega sveta označujejo nižje temperature (povprečna letna temperatura 2 do $4{ }^{\circ} \mathrm{C}$, na najvišjih grebenih Kamniško-Savinjskih Alp 0-2 ${ }^{\circ} \mathrm{C}$; Letna povprečna temperatura zraka, 1981-2010, 2016), velika namočenost (povprečna letna višina padavin od 2000 do 2600 mm; Povprečna letna vsota korigiranih padavin, 2016), visoka in dolgotrajna snežna odeja (povprečna skupna višina novozapadlega snega nad 3 m, od 150 do nad 200 dni s snežno odejo; Povprečna skupna višina novozapadlega snega v sezoni, 2016; Povprečno število dni s snežno odejo v sezoni, 2016) in dobra prevetrenost (povprečna letna hitrost vetra $10 \mathrm{~m}$ nad tlemi od 5 do $7 \mathrm{~m} / \mathrm{s}$; Rakovec in sod., 2009, str. 102).

Pri osončenosti je zaradi strmega reliefa prisoten kontrast med dobro obsijanimi prisojnimi (povprečna letna energija Sončevega sevanja 1300 do $1660 \mathrm{kWhm}^{-2}$ ) in slabo obsijanimi osojnimi pobočji (manj kot 200 do $800 \mathrm{kWhm}^{-2}$ ). Nad prisojnimi pobočji, tako v goratem kot tudi nižjem, hribovitem delu obravnavane pokrajine, je čez dan ob jasnem in mirnem vremenu prisotno dviganje ogretega zraka (dolnik). Ponoči pa se iz višjih predelov v nižje steka hladen zrak (gornik). Posebno topoklimo imajo neporaščeni in slabo poraščeni grebeni in vrhovi (topoklima izrazito konveksnih predelov), ki so ob radiacijskem vremenu, še posebej pozimi, zelo dobro osončeni, zelo prevetreni in izpostavljeni vetrovom vseh smeri in hitrosti, hkrati so v topli polovici leta čez dan pogosto zaviti v kopasto oblačnost. V rastni sezoni imajo posebno topoklimo grmišča in travišča ter predeli $\mathrm{z}$ redkim rastlinstvom ali brez njega. V odvisnosti od barve, vlažnosti in poroznosti prsti (matične podlage) se golo ali slabo poraščeno površje čez dan zelo segreje, ponoči pa zelo ohladi, zato imajo take površine velike dnevne temperaturne amplitude.

Topoklimo nižjega gorskega sveta ima preostali, pod zgornjo gozdno mejo ležeči del obravnavane pokrajine. Njeno jedro predstavlja Jezerska kotlinica z Ravensko in 
Makekovo Kočno. Zaradi nižje nadmorske višine ima ta topoklimat višje temperature zraka (povprečna letna temperatura 2 do $6{ }^{\circ} \mathrm{C}$; Letna povprečna temperatura zraka, 19812010, 2016) in nekoliko manj padavin (povprečna letna višina padavin 1800-2000 mm; Povprečna letna vsota korigiranih padavin, 2016), manj je tudi dni s snežno odejo (od 100 do 150 dni; Povprečno število dni s snežno odejo v sezoni, 2016), ki je tudi nižja (od 200 do 280 cm; Povprečna skupna višina novozapadlega snega v sezoni, 2016). Vsi podatki so za obdobje 1971-2000. Večji del pokrajine je srednje osončen (povprečna letna energija Sončevega sevanja od 800 do $1300 \mathrm{kWhm}^{-2}$ ). Po slabi osončenosti in manj prejeti energiji Sončevega obsevanja (povprečna letna energija Sončevega sevanja pod $800 \mathrm{kWhm}^{-2}$ ) izstopajo jugozahodna (osojna) pobočja nad Makekovo in Ravensko Kočno, južna pobočja med Zgornjim in Spodnjim Jezerskim ter posamezne globoke grape. Dobro osončen (povprečna letna energija Sončevega obsevanja 1300 do $1660 \mathrm{kWhm}^{-2}$ ) je predvsem severni in severozahodni karavanški obod Jezerske kotlinice in posamezna južno orientirana pobočja nad Ravensko in Makekovo Kočno.

Čeprav razmere za nastanek izrazitih jezer hladnega zraka zaradi odprtosti kotlinice in stekanja hladnega zraka proti dolini Kokre niso idealne, v Jezerski kotlini z Ravensko in Makekovo Kočno ob radiacijskem tipu vremena redno nastaja temperaturni obrat. Intenziteta toplotnega obrata ni velika, po naših meritvah od 3,5 (topla polovica leta) do $6{ }^{\circ} \mathrm{C}$ (pozimi), prevladujejo plitve inverzije. Zaradi pestrejše rabe tal je mozaik topoklimatskih enot nižje ravni bolj raznolik kakor v predelih nad zgornjo gozdno mejo. Pri ugotavljanju temperaturnih značilnosti različnih tipov rab in izločanju enot smo si pomagali s termalnimi posnetki površja (Vysoudil, Ogrin D., 2009). Analiza posnetkov je pokazala velike razlike med posameznimi predeli v odvisnosti od tipa aktivnega površja, pa tudi od ekspozicije in naklona. Na topoklimatski karti izdvajamo podnebje poraščenih (gozdnih) površin in podnebje manj intenzivno poraščenih in kmetijskih površin ter posebno podnebje, ki ga v primeru Jezerskega tvorijo razpršeno pozidani predeli. Če je površje prekrito z rastlinstvom, se ustvari posebno mikroklimatsko okolje, ki modificira absorbcijo Sončevega sevanja, izgube terestričnega sevanja in zračne tokove. Energija Sončevega sevanja se ne absorbira v eni plasti, ampak nekaj na vrhu rastlinskega pokrova, nekaj v pokrovu, del pa tudi v tleh. Pri zelo sklenjenem rastlinskem pokrovu je aktivna plast pri vrhu. V tem primeru so temperature podnevi nižje pri tleh, ponoči pa na vrhu rastlinskega pokrova. Kratkotrajne primerjalne meritve v mešanem gozdu in na travniku na Zgornjem Jezerskem maja v obdobju 2013-2015 so pokazale, da so bile najvišje dnevne temperature v gozdu za okoli $3{ }^{\circ} \mathrm{C}$ nižje kot na travniku, minimalne pa za $2,5^{\circ} \mathrm{C}$ višje. $\mathrm{V}$ gozdu je bila povprečna dnevna temperaturna amplituda za $2,1^{\circ} \mathrm{C}$ nižja kot na travniku. Ob plohi 12. 5. 2014 je v gozdu padlo $10,5 \mathrm{~mm}$ padavin, na travniku $19 \mathrm{~mm}$, ob prevladi šibkih vetrov je bila povprečna hitrost vetra za okoli $1 \mathrm{~m} / \mathrm{s}$ nižja kot na odprtem.

Naselje Zgornje Jezersko, čeprav je relativno majhno in ni gosto pozidano, tvori glede na termalne posnetke manjši toplotni otok, kjer je temperatura površja za nekaj stopinj

Slika 6 (na naslednji strani): Topoklimatska karta Jezerskega.

Figure 6 (overleaf): Topoclimatic map of Jezersko. 


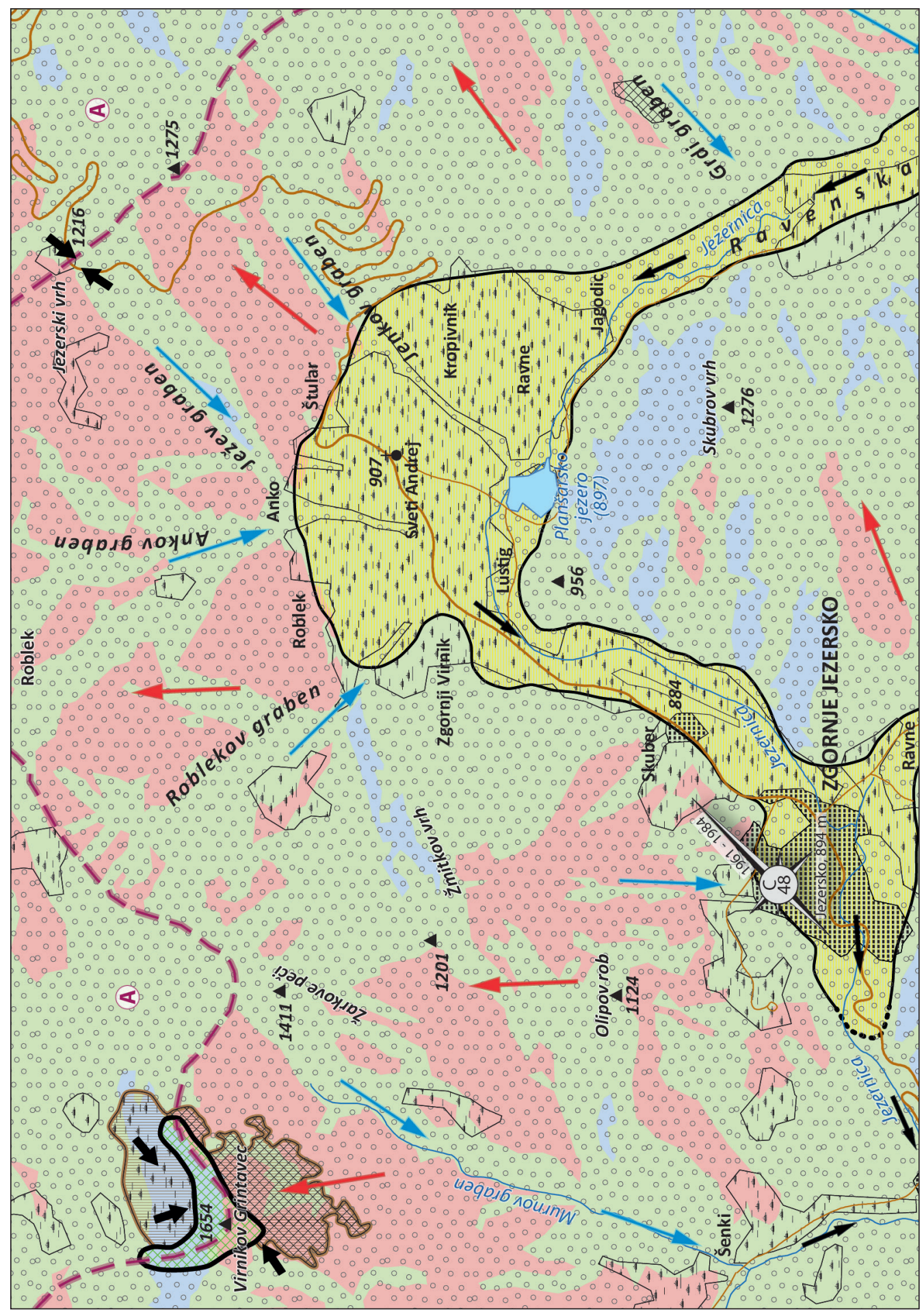




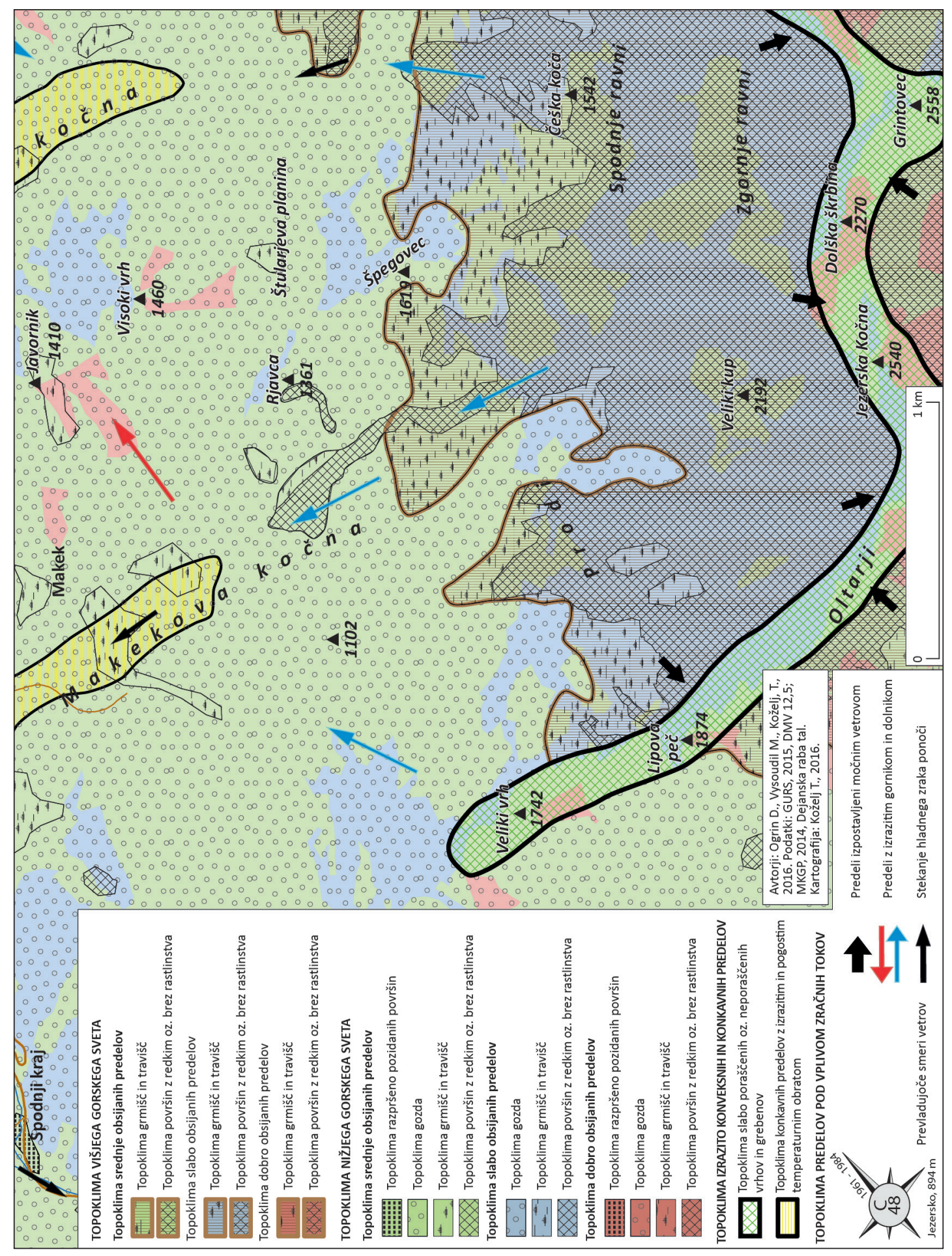


višja od nepozidane okolice (slika 7). Stavbe dodatno zastirajo horizont in ob visokem južnem obzorju še skrajšujejo Sončevo obsevanje, najbolj občutno pozimi. Na glavni ulici le na dveh od šestih merilnih mestih sonce pozimi posije za od 20 minut do $1 \mathrm{~h} 20$ min, ostala merilna mesta so v tem času brez neposrednega Sončevega sevanja. Okoli poletnega obrata imajo v naselju teoretično 6 do 12 ur s soncem.

Slika 7: Naselje Zgornje Jezersko je imelo 14. 5. 2014 okoli 17 približno $4{ }^{\circ} \mathrm{C}$ višjo temperaturo površja od travnate in gozdnate okolice (termalni posnetek in njegova obdelava: M. Vysoudil).

Figure 7: On 14 May 2014 at about 5 p.m. the temperature at the settlement of Zgornje Jezersko was nearly $4^{\circ} \mathrm{C}$ higher than the temperature of the grassy and wooded surroundings surface (Thermal images and their processing: M. Vysoudil).

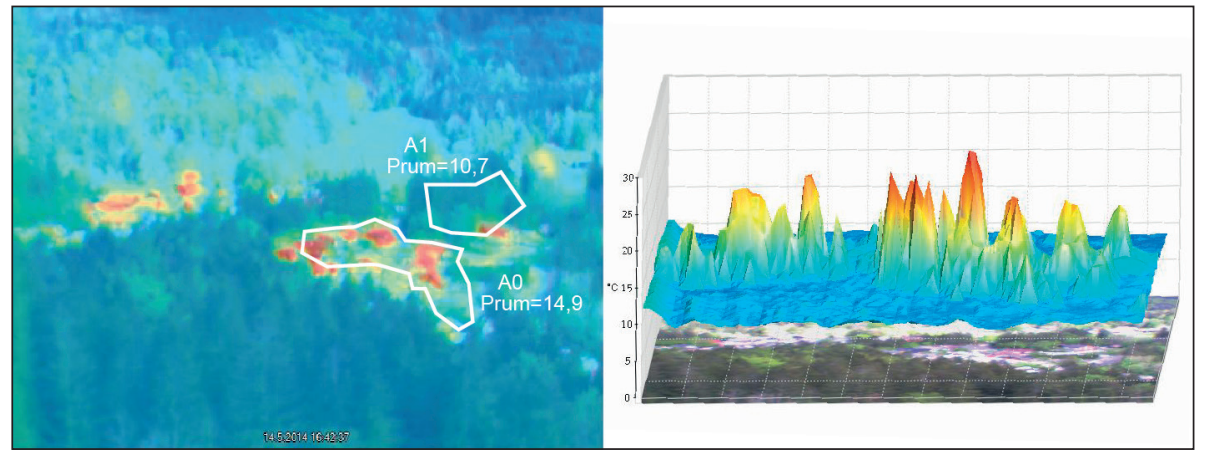

\section{SKLEP}

Topoklimatska karta Jezerskega v merilu 1 : 25.000 zaradi velike razčlenjenosti površja in generalizacij, povezanih z njim, ne dopušča prikaza vseh podrobnosti topoklimatskih razmer. Marsikateri od teh pojavov je bil med raziskovalnim delom zaznan, vendar je bil zaradi različnih okoliščin slabo raziskan, zato ga v pojasnjevalnem besedilu in na karti nismo prikazali. Zaradi tega je potrebno karto brati kot nekoliko posplošen prikaz lokalnih in nekaterih mikroklimatskih značilnosti. V uporabne namene, npr. kot pomoč pri izdelavi prostorskih načrtov in umeščanju dejavnosti v prostor, bi potrebovali karto v večjem merilu. Ta bi morala temeljiti na podrobnejšem terenskem opazovanju in merjenju lokalnih podnebnih razmer v daljšem časovnem obdobju, kakor smo ga imeli na razpolago, in na uporabi dodatnih, posrednih in neposrednih metod topoklimatskega raziskovanja.

\section{Zahvala}

Rezultati o lokalnem podnebju Jezerskega v veliki meri izhajajo iz terenskih meritev in opazovanj, ki so potekala v okviru terenskih vaj iz fizične geografije s študenti 2. letnika Oddelka za geografijo Filozofske fakultete Univerze v Ljubljani v študijskih letih 
od 2012/13 do 2014/15 in seminarja iz klimatogeografije. Podkrepljeni so s termalnimi posnetki površja, ki so nastali v okviru sodelovanja Oddelka za geografijo Filozofske fakultete Univerze v Ljubljani z Oddelkom za geografijo Fakultete za naravoslovje Palackýjeve univerze v Olomoucu na Češkem. Vsem sodelujočim se avtorji prispevka najlepše zahvaljujemo za trud.

\section{Literatura in viri}

Arhiv meteoroloških podatkov ARSO. Povprečne mesečne in letne temperature zraka za Preddvor v obdobju 1992-2011. URL: http://meteo.arso.gov. $\mathrm{si} / \mathrm{met} / \mathrm{s} 1 / \mathrm{app} / \mathrm{webmet} /$ \#webmet $==8 \mathrm{Sdw}$ 2 bhR2cv0WZ0V2bvEGcw $9 \mathrm{y}-$ dlJWblR3LwVnaz9SYtVmYh9iclFGbt9SaulGdugXbsx3cs9md15WahxXYyNGapZXZ8tHZv1WYp5mOnMHbvZXZulWYnwCchJXYtVGdlJnOn0UQQdSf; (citirano 14. 10. 2016).

Barry, R. G., Hall-McKim, E. A., 2014. Essentials of the Earth's climate syste. New York, Cambridge University Press, 259 str.

Buser, S., Cajhen, J., 1975. Osnovna geološka karta SFRJ, list Celovec. Beograd, Zvezni geološki zavod.

Digitalni model višin 12,5. Ljubljana, Geodetska uprava RS, 2015.

Evidenca dejanske rabe kmetijskih in gozdnih zemljišč (stanje 13. 1. 2014). Ministrstvo za kmetijstvo, gozdarstvo in prehrano, 2014.

Evidenca gozdnih sestojev. Zavod za gozdove Slovenije, 2012.

Furlan, D., Košir, D., 1976. Klima Jezerskega in njena klimatsko-terapevtska vrednost. Elaborat. Meteorološki zavod SR Slovenije.

Gabrovec, M., 1996. Solar Radiation and Diverse Relief of Slovenia. Geografski zbornik, 34, str. 47-68.

Gams, I. 1972. Prispevek k mikroklimatologiji vrtač in kraških polj. Geografski zbornik, 13, $77 \mathrm{str}$.

Gams, I., 1996. Termalni pas v Sloveniji. Geografski vestnik, 68, str. 5-38.

Januarska povprečna temperatura zraka, obdobje 1981-2010, 2016. URL: http://meteo. arso.gov.si/uploads/probase/www/climate/image/sl/by_variable/temperature/january-mean-air-temperature_81-10.png (citirano 14. 11. 2016).

Jernej, S., 2000. Mestna k̄lima Ljubljane. V: Gabrovec, M., Orožen Adamič, M. (ur.). Ljubljana - geografija mesta. Ljubljana, LGD in Založba ZRC, str. 117-130.

Julijska povprečna temperatura zraka, obdobje 1981-2010, 2016. URL: http://meteo. arso.gov.si/uploads/probase/www/climate/image/sl/by_variable/temperature/july-mean-air-temperature_81-10.png (citirano 14. 11. 2016).

Kastelec, D., Rakovec, J., Zakšek, K., 2007. Sončna energija v Sloveniji. Ljubljana, ZRC SAZU, 136 str.

Kataster stavb. Geodetska uprava RS, 2016.

Klimatografija Slovenije, Temperatura zraka 1961-1990, 1995. Ljubljana, HMZ RS MOP, 356 str. 
Konovšek, A., 2006. Mezoklimatske razmere Šaleške doline in mesta klima Velenja. V: Šalej, M., (ur.). Šaleška in Zgornja Savinjska dolina. Zbornik 19. zborovanja slovenskih geografov, Velenje 2004. Velenje, Erico, Inštitut za ekološke raziskave, str. 76-87.

Letna povprečna temperatura zraka, obdobje 1981-2010. URL: http://meteo.arso.gov. si/uploads/probase/www/climate/image/sl/by_variable/temperature/annual-mean-air-temperature_81-10.png (citirano 14.11.2016).

LIDAR. Agencija RS za okolje, 2015.

Lovrenčak, F., 2007. Zgornja gozdna meja slovenskih Alp, visokih kraških planot in Prokletij. Ljubljana, Razprave Filozofske fakultete, 217 str.

Mičietová, E., Pavličko, P., 2000. Metodika tvorby topoklimatických máp v prostredí geoinformačných technológii. Kartografické listy, 8, str. 99-116.

Ogrin, D. 2008. Splošne in lokalne podnebne značilnosti Bele Krajine. V: Plut, D. (ur.). Bela Krajina in Krajinski park Lahinja. Ljubljana, Znanstvena založba Filozofske fakultete, str. 71-90.

Ogrin, D., 1996. Podnebni tipi v Sloveniji. Geografski vestnik, 68, str. 39-56.

Ogrin, D., 2000. Nekatere topoklimatske značilnosti razporejanja temperature zraka in burje v razgibanem reliefu Slovenije. Dela, 15, str. 125-138.

Ogrin, D., 2005. A contribution to the definition of thermal belt in Sub-pannonian Slovenia. Geographica Pannonica, 9, str. 4-8.

Ogrin, D., 2007. Uporabnost kartiranja vinogradov kot metode za ugotavljanje prostorskih značilnosti termalnega pasu. Dela, 28, str. 121-132.

Ogrin, D., Krevs, M., 1995. Nekateri rezultati klimatskih meritev v Planici s poudarkom na meritvah terminalnih poganjkov dreves. Dela, 11, str. 21-45.

Ogrin, D., Mužina, D., 2005. Pokrajinskoekološke značilnosti območja med Kavčičem in Tinjanom. V: Rožac Darovec, V. (ur.). Meje in konfini. Koper, Univerza na Primorskem, Znanstveno-raziskovalno središče Koper, Zgodovinsko društvo za južno Primorsko, Založba Annales, str. 289-332.

Ogrin, D., Vysoudil, M., 2011. Topoklimatska karta obalnega pasu Slovenske Istre. Dela, 35 , str. 5-25.

Ogrin, D., Vysoudil, M., Ogrin, M., 2013. Splošne podnebne razmere Gorenjske in lokalno podnebje Kamniške Bistrice. V: Rogelj, B., Potočnik Slavič, I., Mrak, I. (ur.). Gorenjska v obdobju glokalizacije. Ljubljana, Znanstvena založba Filozofske fakultete, str. 9-29.

Ogrin, M., 2005. Značilnosti temperaturnih inverzij v osrednjem delu Ljubljanske kotline. Geografski obzornik, 52, 2, str. 24-27.

Ogrin, M., 2007. The minimum temperatures in the winter 2006/07 in Slovenian frost hollows and cold basins. Dela, 28, str. 221-237.

Ogrin, M., Sinjur, I., Ogrin, D., 2006. Minimalne temperature v slovenskih mraziščih pozimi 2005/2006. Geografski obzornik, 53, 2, str. 4-12.

Ortar, J., Ogrin, M., Vertačnik, G., Sinjur I., 2010. Primerjava temperaturnih razmer v mraziščih Reovce (Orjen), Valoviti do (Durmitor), Luknja in Mrzla Komna (obe Julijske Alpe) v meteorološki zimi 2007/2008. V: Geoekologija - XXI vijek, Teorijski i aplikativni zadaci. Zbornik referatov GEOEKO 2010. Žabljak-Nikšič, str. 553-561. 
Pintar, P., 2015. Najnižje temperature na Jezerskem pozimi 2013/2014 in 2014/2015. Zaključna seminarska naloga. Ljubljana, Univerza v Ljubljani, Filozofska fakulteta, Oddelek za geografijo, 35 str.

Polčák, N., 2000. Možnosti spracovania mezoklímy a miestnej klímy v územiach s chýbajúcou klimatickou databázou na príklade Biosférickej rezervácie Východné Karpaty. Geografický časopis, 52, str. 181-191.

Polčák, N., 2001. Analýza teplotných inverzií v Banskej Bystrici na základe terénnych pozorovaní. V: Turisová, I (ur.). Ekologická diverzita modelového územia Banskobystrického regiónu. FPV UMB, Štátna ochrana prírody SR, Stredoslovenské múzeum, Banská Bystrica, str. 55-65.

Popovič, B., 1992. Jezersko - klimatsko zdravilišče. Geografski obzornik, 39, 1, str. 22-23.

Povprečna letna višina korigiranih padavin, obdobje 1971-2000. URL: http://meteo.arso. gov.si/uploads/probase/www/climate/image/sl/by_variable/precipitation/mean-annual-corrected-precipitation_71-00.png (citirano 8. 9. 2016).

Povprečna skupna višina novozapadlega snega v sezoni (1971/72-2000/01). URL: http:// meteo.arso.gov.si/uploads/probase/www/climate/image/sl/by_variable/snow/meanseasonal-fresh-snow-accumulation_71-00.png (citirano 8.9. 2016).

Povprečno število dni s snežno odejo v sezoni (1971/72-2000/01). URL: http://meteo. arso.gov.si/uploads/probase/www/climate/image/sl/by_variable/snow/mean-seasonal-snow-cover-duration_71-00.png (citirano 8. 9. 2016).

Quitt, E. 1990. Methods, result and perspectives of topoclimatic mapping in Czechoslovakia. V: Grzybowski, J. (ur.). Problems of contemporary topoclimatology, Conference papers 4. Warzsawa, Institut of Geography and Spatial Organization, Polish Academy of Science, str. 11-18.

Quitt, E., 1965. Metody konstrukce mezoklimatických map. Sborník Československé společnosti zeměpisné, 3 , str. 232-250.

Quitt, E., 1994. Topoclimatic map as a basis for atmosphere protection and regional development of the landscape. Moravian Geographical Reports, 2, str. 12-17.

Rakovec, J., Žagar M., Bertalanič, R., Cedilnik, J., Gregorič, G., Skok, G., Žagar, N., 2009. Vetrovnost v Sloveniji. Ljubljana, Založba ZRC, 177 str.

Selčan, A., Tomić, T., 2010. Podnebje občine Tolmin. V: Občina Tolmin, Sotočje mladih možganov in aktualnih izzivov, 14. geografski raziskovalni tabor, Volče. Ljubljana, Društvo mladih geografov Slovenije, str. 49-55.

Sončno sevanje in obsevanje, 2016. PVportal, slovenski portal za fotovoltaiko, URL: pv.fe.uni-lj.si./Obsevanje.aspx (citirano 14. 11. 2016).

Strle, D., 2015. Pojav znižane meje sneženja na primeru doline Planice. Zaključna seminarska naloga. Ljubljana, Univerza v Ljubljani, Filozofska fakulteta, Oddelek za geografijo, 51 str.

Sulzer, W., 2002. Climatological research and its possible contribution to regional planning in an Alpine environment. V: Steininger, K. W., Weck-Hannemann, H. (ur.). Global environmental change in Alpine regions - Recognition, impact, adaptation and mitigation. Cheltenham, Edward Edgar Publishing Ltd., str. 150-162. 
SURS, 2015. Število prebivalcev v naselju Zgornje Jezersko. URL: http://www.stat.si/ krajevnaimena/pregledi_naselja_najvecja.asp?tlist $=$ off\&txtIme=ZGORNJE\%20JEZERSKO\&selNacin $=$ celo\&selTip $=$ naselja\&ID $=5532$ (citirano 25. 8. 2016).

Vysoudil, M. in sod., 2012. Podnebí Olomouce. Olomouc, Universita Palackého v Olomouci, 212 str.

Vysoudil, M., 1993. Topoclimatic Mapping in Central Moravia (Czech Republic). Geografski vestnik, 65 , str. $25-31$.

Vysoudil, M., 1997. Bioclimate and air quality assessment in the cultural landscape by use topoclimatic maps. V: Hočevar, A., Črepinšek, Z., Kajfež-Bogataj, L. (ur.). Biometeorology - Proceedings of $14^{\text {th }}$ International Congress of Biometeorology. Ljubljana, Inernational Society of Biometeorology in Slovensko meteorološko društvo, str. 311-316.

Vysoudil, M., 2000. Topoklimatické mapování: Od teorie k praxi. Geografický časopis, 52,2 , str. $2-13$.

Vysoudil, M., 2009. Klasifikace místnich klimatických efektu. Geografický časopis, 61, 3 , str. 229-241.

Vysoudil, M., Ogrin, D., 2009. Portable infrared camera as a tool in topoclimatic research. Dela, 31, str. 115-127.

Žiberna, I., 1991. Nekatere značilnosti mestne klime Maribora. Dela, 8, str. 72-77.

Žiberna, I., 1992. Vpliv klime na lego in razširjenost vinogradov na primeru srednjih Slovenskih goric. Geografski zbornik, 32, str. 50-139.

Žiberna, I., 1999. Temperaturni obrat v hriboviti Sloveniji. Dela, 13, str. 237-248.

\section{LOCAL CLIMATE AND TOPOCLIMATIC MAP OF JEZERSKO}

\section{Summary}

The term topoclimate denotes special local climate conditions which occur under the influence of the Earth surface characteristics, mainly of land forms and land use. However, the basic features depend on regional and also global circumstances. The paper discusses the topoclimatic features of Jezersko (northern Slovenia), which is situated at the transition of the Karavanke to the Kamnik-Savinja (Kamniško-Savinjske) Alps. The core of the landscape consists of the Jezerska kotlinica basin with the glacial valleys of Ravenska Kočna and Makekova Kočna (900-1,000 m a.s.l.) which are surrounded by 1,600 to 2,500 $\mathrm{m}$ high mountain ridges. Topoclimatic characteristics were established by means of combining direct methods, i.e. detailed field measurements and observations, and indirect methods in which analyses of land forms, vegetation conditions and land use were applied to show local and micro climate features. The synthesis of the investigation resulted in a topoclimatic map in the scale of 1:25,000.

Basically, Jezersko is divided into two topoclimatic units: higher mountainous and lower mountainous unit. The topoclimate of the higher mountains occurs in the mountainous surroundings of the investigated landscape which reaches beyond the upper tree line. It is typical for lower air temperatures (average annual air temperature: from $0{ }^{\circ} \mathrm{C}$ 
to $4{ }^{\circ} \mathrm{C}$ ), abundant precipitation (average annual height 2000-2600 $\mathrm{mm}$ ), thick and longlasting snow cover and good windiness, of mountain ridges in particular. Due to steep landforms a contrast in insolation is evident between well insolated sunny slopes (average annual energy of solar radiation from 1300 to $1600 \mathrm{kWh} / \mathrm{m}^{2}$ ) and poorly insolated shady slopes (less than $200-800 \mathrm{kWh} / \mathrm{m}^{2}$ ). Above the sunny slopes, both in mountainous and lower, i.e. hilly, parts of the discussed landscape, the warmed air (valley wind) ascends during the days with clear and calm weather. At night, cool air (mountain wind) descends from the higher- to the lower-lying world. A special topoclimate occurs on bare and sparsely overgrown ridges and peaks (topoclimate of explicitly convex areas) which are during the radiation weather, in winter in particular, very well insolated, well windy and exposed to winds from all directions and of various speed; while in the warm half of a year they are often covered with cap cloudiness. During the growth season, special topoclimate occurs over the shrubby and grass areas and areas with thin vegetation or without it. Depending on the colour, moisture and permeability of soil (parent material) the bare or poorly overgrown surface warms very much during the day, and cools very much at night, therefore such surfaces manifest high amplitudes in daily temperatures.

The topoclimate of lower mountainous unit of Jezersko occurs in the remaining part of the discussed landscape, lying under the tree line. The Jezerska kotlinica basin with Ravenska Kočna and Makekova Kočna represent the core of this unit. Due to a lower altitude above sea level, this topoclimatic unit has higher air temperatures (average annual temperature $2-6^{\circ} \mathrm{C}$ ) and a slightly lesser amount of precipitation (average annual precipitation height 1800-2000 mm), and fewer are also the days with snow cover (100-150 days). The major part of the landscape gets medium insolation (average annual solar radiation energy is $800-1300 \mathrm{kWh} / \mathrm{m}^{2}$ ). Special for their poor insolation and lesser amount of solar radiation are southwestern (shady) slopes above Makekova Kočna and Ravenska Kočna, southern slopes between Zgornje Jezersko and Spodnje Jezersko, and individual deep ravines. Well insolated is mainly the northern and northwestern Karavanke rim of the Jezerska kotlinica basin and individual south-oriented slopes above Ravenska Kočna and Makekova Kočna. Although conditions for the development of explicit lakes of cold air are not ideal, due to the openness of the basin and convergence of cold air towards the Kokra valley, temperature inversion regularly occurs in the Jezerska kotlinica basin with Ravenska Kočna and Makekova Kočna, with the radiation type of weather. The intensity of temperature inversion is not to big - from $3.5^{\circ} \mathrm{C}$ (warm half of year) to $6^{\circ} \mathrm{C}$ (winter) according to our measurements - and shallow inversions prevail. The mosaic of topoclimatic units at the lower level is more varied, due to more versatile land use, than that of the areas above the tree line. Three different types are shown in the topoclimatic map: the climate of overgrown (forest) areas; the climate of less intensely overgrown and farming areas; and a special climate which is formed in the case of Jezersko by dispersed built-up areas.

Due to big differences in the heights of the surface and ensuing generalization, the topoclimatic map of Jezersko in the scale of 1:25,000 does not allow presenting all the details in topoclimatic conditions. Therefore, the map should be read as a slightly generalized illustration of local and certain microclimatic characteristics. For applicable 
purposes, e.g. as a help in making spatial plans and locating activities in the space, a map of a bigger scale would be necessary. This should be based on detailed field observations and measurements of local climate conditions over a longer span of time and on the use of additional, indirect and direct methods of topoclimatic research.

(Translated by Branka Klemenc) 